\title{
Comprehensive sexuality education to reduce pregnancy and STIs in adolescents in the United States: A systematic review and meta-analysis
}

\author{
Amy L. Bordogna ( $\square$ amy.bordogna.gr@dartmouth.edu ) \\ The Dartmouth Institute for Health Policy \& Clinical Practice, Geisel School of Medicine at Dartmouth College
}

\section{Research article}

Keywords: abstinence, adolescent, comprehensive sexuality education, pregnancy, sexually transmitted infections

Posted Date: September 21st, 2021

DOI: https://doi.org/10.21203/rs.3.rs-764336/v1

License: (a) (1) This work is licensed under a Creative Commons Attribution 4.0 International License. Read Full License 


\section{Abstract \\ Background.}

The United States has a higher rate of teen pregnancy than any other developed country with $30 \%$ of American girls becoming pregnant before the age of 20 . Laws regarding the inclusion and content of sexuality education vary across the country, which are associated with differences in pregnancy and sexually transmitted infection (STI) rates between states. This systematic review aims to determine whether comprehensive sexuality education (CSE) is more effective than abstinence-only or no sexuality education at reducing teenage pregnancy. Secondary objectives include analyzing the effect of CSE on STI incidence, sexual activity, safe-sex behaviors, and social discomfort.

\section{Methods.}

We searched MEDLINE (PubMed), EMBASE (Ovid), Cochrane Central Register of Controlled Trials, and Scopus for studies published from $1990-2021$. Additionally, we searched ClinicalTrials.gov and Google Scholar and manually searched reference lists of included papers.

\section{Results.}

Twenty-nine studies met our inclusion criteria. Only seven included pregnancy as an outcome, with three fitting our meta-analysis criteria. There was a decrease in pregnancy rates for participants in the CSE intervention compared to the control $\left(n=3\right.$, risk ratio $\left.=0.89,95 \% \mathrm{Cl} 0.79-1.00, \mathrm{I}^{2}=0 \%\right)$. Fifteen of 21 studies reporting safe-sex behaviors, 8 of 24 reporting sexual activity, and 0 of 3 reporting STI rates found statistically significant results favoring CSE. In the narrative synthesis, we found an increase in safe-sex behaviors, specifically condom use, in adolescents receiving CSE compared to no intervention.

\section{Conclusions.}

CSE is likely to reduce pregnancy rates; however, there was limited data available on this outcome. CSE increased safe-sex behaviors but did not have a notable impact on sexual activity or STIs. Future research should include the effects of CSE on social discomfort as well as more studies comparing CSE to abstinence-only education. This review can serve as evidence for the implementation of CSE in the US.

\section{Background}

Compared to other western developed countries, the United States (US) has a higher rate of teen pregnancy with persistent racial/ethnic, socioeconomic, and geographic disparities.[1, 2] The birth rate in 2014 for Hispanic and non-Hispanic Black females aged 15-19 was 39.8 and 37.0 per 1000 , respectively, compared to 18.0 for White females.[3] Furthermore, low socioeconomic status is highly correlated with an increase in teenage pregnancies, with states clustered in the south and southwest regions with overall low socioeconomic status having higher rates. [2, 4] Seventy-five percent of these teenage pregnancies were unintended, and women who were non-Hispanic Black or whose income was below the poverty line were more likely to report an unintended pregnancy.[5] Teenage pregnancy is often associated with greater health risks, including eclampsia, postpartum endometritis, and systemic infections in the mother.[5] Teenage pregnancy can increase school dropout rates, limit future opportunities, and lead to rejection or violence from partners, guardians, or society.[4] Additionally, more than half of incident sexually transmitted infections (STIs) are diagnosed in individuals aged 15-24.[6] The disparities above shed light on the need for the US to provide successful interventions to reduce the rates of STIs and teenage pregnancy.

Adolescent sexuality education in the US varies by state, municipality, and school. Twenty-nine states mandate sexuality education in schools, 37 require sexuality education to cover abstinence, and 18 require information to be provided on birth control.[7] Only 15 states require the education to be medically accurate.[7] Comprehensive sexuality education (CSE) involves the physical and psychosocial sides of sexuality to promote healthy and safe sexual behaviors.[8] CSE can also include information on the benefits of abstinence. Abstinence-only education focuses only on waiting until marriage to have sex. [9] It has not been shown to reduce sexual behavior or unplanned pregnancy rates, and some studies have seen an increase in teenage pregnancy rates resulting from an abstinence-only education. $[9,10]$ A positive correlation was found between states with the highest-emphasis on abstinence-only education and teen pregnancy rate.[10] Arkansas, which has the highest rate of teen pregnancy at 30.4 per 1000, requires sexuality education to stress abstinence.[7] Conversely, Massachusetts, with the lowest rate at 7.2 per 1000, requires that sexuality education be culturally appropriate and unbiased, without a mandated stress on abstinence-only.[7] Alaska, with the highest rate of chlamydia, one of the most common STIs in the US, at 832.5 per 100,000 , has no requirements for sexuality education.[11-13] West Virginia, with the lowest rate of chlamydia at 198.2 per 100,000, mandates that sexuality education covers contraception and condoms, in addition to abstinence.[7, 12] Prior research has focused primarily on school-based CSE interventions, but adolescents can learn in other settings, including at home or in the community. A systematic review on studies conducted in the US comparing CSE to abstinence-only or no sexuality education delivered in various settings has not been completed.

The objective of this review was to determine the extent to which CSE during adolescence (ages 10-18) in the US is beneficial in reducing teen pregnancy and STIs compared to abstinence-only or no sexuality education. As an intermediary measure of behaviors that reduce teen pregnancy and STIs, we also looked at how CSE programs impacted safe-sexual behaviors, such as condom use, and sexual activity levels.

\section{Methods}


We followed the Preferred Reporting Items for Systematic Reviews and Meta-Analyses (PRISMA) protocol.[14] The study was registered within the Open Science Framework (OSF) platform prospectively (OSF: osf.io/t6yku) on March 2, 2021. The original protocol is available upon request and a log of changes made after starting the formal review can be found in Appendix 1.

\section{Study Eligibility}

The inclusion criteria with justifications we used to determine study eligibility are in Appendix 2. We included randomized controlled trials (RCTs) that (1) included adolescents between 10 and 18 with at least $50 \%$ of participants under 24 , (2) had a CSE intervention group, (3) had an abstinence-only or no intervention control group, and (4) reported on pregnancy (primary outcome), STIs, safe-sex behaviors, sexual activity, or social discomfort. Pregnancy included females reporting they were pregnant and/or males reporting they got someone pregnant.

\section{Search Methods}

\section{Databases, Search Terms, and Limits}

In collaboration with a research librarian we developed a comprehensive search strategy that was executed in MEDLINE (PubMed), EMBASE (Ovid), Cochrane Central Register of Controlled Trials, and Scopus from 1990 to January 28, 2021. See Appendix 3 for full information on our search strategy. We limited our search to (1) studies in English due to resource-restrictions, and (2) studies published after 1990 because the publication of the SIECUS Guidelines for CSE for school-aged children and adolescents in 1991 marks a shift in the field of sexuality education.[8] This was the first national approach and framework indicating what should be covered in sexuality education at various ages. We therefore decided to focus our study on what has been deemed the "modern era" of sexuality education.[8]

\section{Additional Search Methods}

We also searched: (1) ClinicalTrials.gov from inception to January 21, 2021, (2) reference lists of included papers, and (3) the first 100 hits on Google Scholar from 1990-2021. The strategies and results for these additional search methods are outlined in Appendix 3.

\section{Study Selection}

We used EndNote (Clarviate Analytics) for deduplication then Rayyan for primary and secondary screening.[15] For the primary screen, two independent screeners per reference ( $\mathrm{AB}, \mathrm{AC}$, or RN) scanned identified studies' titles and abstracts for inclusion. The two screeners discussed identified disagreements and brought in a third screener $(A B, A C$, or $\mathrm{RN})$ for resolution when needed. The same process was followed for full-text review including documenting reasons for study exclusion.

\section{Data Extraction}

Two blinded researchers per reference (AB, AC, or RN) independently extracted data for all included articles according to a predefined data collection form in Google Sheets. After extraction, a third author was used to discuss any discrepancies. After piloting the form using two included articles to ensure consistency amongst reviewers, we extracted specific data on study details, outcome data, and methodological quality. The full list of items extracted is in Appendix 4. For all endpoint data, we extracted outcomes at one-year of follow-up. If one-year data was not reported, we extracted the last follow-up time point result reported.

\section{Quality Assessment}

We used the Grading of Recommendations, Assessment, Development and Evaluations (GRADE) approach to assess the quality and strength of evidence across all included studies.[16, 17] This tool rates the level of certainty for outcomes of included studies as high, moderate, low, or very low (H/M/L/VL) for the following domains: risk of bias, inconsistency of results, indirectness of evidence, imprecision, publication bias, large magnitude of effect, dose-response gradient, and residual confounding. We used GRADE for the primary outcome of each study.

\section{Assessment of Bias}

We reviewed the risk of bias of each study using Version 2 of the Cochrane risk-of-bias tool for randomized trials (RoB 2).[18] Two authors per reference (AC and RN) conducted the risk of bias assessment independently and discussed disagreements. We assessed the risk of bias for the primary outcome of each study.[19] If the primary outcome was not specified, we assessed bias using the outcome authors based their power analysis on or the first outcome reported in the results section.

\section{Statistical Analysis}

\section{Measure of treatment effect:}

We used RevMan 5.4 for statistical analyses.[20] For each included study reporting the primary outcome, pregnancy, we calculated the relative risk (RR) and $95 \%$ confidence interval $(\mathrm{Cl})$ and pooled the findings in a forest plot. We used a random effects model because the studies included were conducted by different researchers and used a variety of populations within the US.[21]

For all secondary outcomes, we qualitatively summarized the results. We completed a narrative summary on how different features of CSE interventions (CSE interventions that emphasized abstinence or were interactive) impacted the reported findings. We opted not to complete a meta-analysis for secondary outcomes because these outcomes included a variety of measures. For example, safe-sex behaviors included condom use, dental dam use, birth control use, and more. 


\section{Dealing with missing data:}

We treated missing outcome data for our primary outcome as "not missing at random" because it may have been indicative of selective reporting bias and/or attrition bias.[22] We therefore opted to impute missing data with replacement values. These replacement values were either the last observation carried forward or a presumed value such as assuming that the intervention had no impact. As the meta-analysis was only planned for our primary outcome, we deemed it appropriate to treat missing data for our secondary outcomes as "missing at random" and analyzed only the available data.

\section{Assessment of heterogeneity:}

We calculated the Higgins $I^{2}$ statistic to assess heterogeneity in sample estimates for the pregnancy outcome.[23] Based on the Cochrane Handbook's guidelines, we set our threshold of $\mathrm{I}^{2}=50 \%$ or higher as indicative of significant heterogeneity.[23]

To assess for heterogeneity in our qualitative analysis, we examined and compared the number of positive, negative, and null findings per outcome domain (sexual activity, safe-sex behaviors, STI prevalence, and social discomfort). We assumed heterogeneity if there was a spread between positive, negative, and null findings. In addition, we addressed potential heterogeneity in CSE interventions by creating subgroups of CSE interventions based on identified features.

\section{Assessment of publication bias:}

We created a funnel plot to assess publication bias for our meta-analysis. By plotting estimates from our study's findings through the log odds ratio against sample size, we determined indirect evidence through the shape of the plot. We used the criteria in the GRADE handbook to assess publication bias for our qualitative analysis.[17]

\section{Subgroup analysis:}

We identified three variables a priori for our subgroup analysis to determine if certain groups yielded different results. These variables were sex (male and female), race/ethnicity (Black, Hispanic, Asian or Pacific Islander, White, and other), and method of CSE delivery (school-, community-, virtual-, and homebased). We also performed a subgroup analysis to provide data on the benefits of CSE over abstinence-only education or no intervention individually to see if the results differed by the type of control.

\section{Sensitivity Analysis:}

We performed a sensitivity analysis based on our methodological quality assessment by excluding studies with some concerns or high risk of bias. To assess the impact of our decision to treat missing data as "not missing at random," we performed a sensitivity analysis excluding studies where we imputed missing data.

\section{Results}

\section{Description of studies}

Results of search

As outlined in Figure 1, we identified 2,015 unique citations after deduplication. After screening titles and abstracts, 162 citations warranted full-text review and 29 citations met our inclusion criteria and were included in our analysis.

\section{Included studies}

Table 1 presents the characteristics of the 29 included RCTs. All were published between 1992 and 2018 in peer-reviewed journals. A total of 23,915 participants were analyzed. There were two RCTs with no intervention as their control group and one RCT with both no intervention and abstinence-only education control groups. Outcomes varied by timeframe (e.g., past 3 weeks, 30 days, 6 months, ever) and metric (i.e., frequency of the event or percent reporting the event).

\section{Included interventions}

The CSE interventions analyzed were not homogenous in content or delivery style. Twelve CSE interventions were school-based, one was virtual, one was home-based, and the remaining 15 were delivered in various settings (see Appendix $\mathbf{5}$ for additional information on the study authors' definitions of CSE interventions). There were nine studies with CSE interventions emphasizing abstinence. Nine studies had interactive CSE interventions, for example, utilizing computer-based activities with virtual exercises.[24]

\section{Risk of Bias and Methodological Quality of Included Studies}

Supplemental Table 1 in Appendix 6 presents our assessment of risk of bias. Studies with the outcomes of pregnancy, STI, safe sex behaviors, and sexual activity had a moderate level of risk of bias based on the domains of randomization process, deviations from intended interventions, missing outcomes, measurement of the outcome, and selection of reported results.

Similarly, some of these outcomes (safe-sex behaviors, pregnancy, and STI rates) had a moderate overall level of methodological quality based on the GRADE assessment and did not report a dose-gradient relationship. In contrast with the other outcomes, studies with the primary outcome of sexual activity had a high level of inconsistency due to a large amount of variation in point estimates and confidence intervals. Out of sixteen studies, only one showed evidence of a dose-gradient relationship[25] This outcome had an overall rating of low for the quality of studies. Further information about the methodological quality of included studies can be found in Supplemental Table 2 in Appendix 6. 


\section{Primary Outcome - Pregnancy}

Seven studies reported pregnancy as an outcome (Table 2), three could be included in our meta-analysis, with a total of 1424 subjects analyzed. Our analysis yielded a RR of 0.89 (95\% Cl: $0.79,1.00)$ with a P-value of 0.05 and an $\mathrm{I}^{2}$ of $0 \%$ (Figure 2). The results favor CSE but are not statistically significant. We determined that our results may be susceptible to publication bias due to the asymmetry of the funnel plot, which likely can be explained by the small number of studies (Supplemental Figure 1 in Appendix 7). However, the three studies we included cover a wide range of sample sizes, which is beneficial for reducing the risk of publication bias.

The remaining four studies either did not provide enough information to calculate the RR or did not include a 12-month follow-up point. In each of these four studies, there was a consistent trend toward fewer pregnancies reported in the CSE intervention group. Two studies yielded statistically significant results. Across all seven studies reporting pregnancy, all favored CSE with four (57.1\%) being statistically significant. Two did not provide enough data to determine significance.

\section{CSE Delivery Method}

We did not have enough studies reporting our primary outcome to perform the planned quantitative subgroup analyses, so we summarized these findings qualitatively. Of the seven studies that reported pregnancy as an outcome, three were school-based, two were home-based, and two were community-based. None of the interventions were conducted virtually. Two found significantly lower pregnancy rates in the school-based delivery subgroup, one found significantly lower pregnancy rates in the home-based delivery subgroup, and one found significantly lower pregnancy rates in the community-based CSE interventions. Based on this analysis, the three delivery methods seem to have similar effectiveness, but more studies are needed to make any final conclusions.

\section{Race and Biological Sex}

We defined the race and sex subgroups as studies with African-American only vs mixed race participants and female only vs mixed sex participants, respectively, since many studies did not report race- or sex-specific data. Only one study reporting on pregnancy had all African-American participants and the remaining six had mixed-race participants. The African-American-only study results were not statistically significant, but favored CSE, while three of the six mixed-race studies had statistically significant results, favoring CSE. The mixed-race studies did not stratify outcomes by race, making it difficult to analyze the impact of race any further. The two studies reporting pregnancy outcomes with female only participants favored the CSE intervention, but were not statistically significant, whereas three of the five mixed-sex studies were statistically significant in favor of CSE.

\section{Intervention Type}

There was one study that reported on pregnancy and had a CSE intervention that emphasized abstinence. This study did not find a statistically significant difference between the intervention and control groups. Of the six studies with a CSE intervention that did not emphasize abstinence and reported pregnancy outcomes three $(50.0 \%)$ found a statistically significant difference in favor of the CSE intervention. Among studies with an interactive CSE intervention that reported on pregnancy $(n=2)$, none found a statistically significant difference between the intervention and control groups. There were five studies without an interactive CSE intervention that reported on pregnancy. Three (60\%) found a statistically significant difference in favor of the CSE intervention.

\section{Sensitivity Analysis}

We were unable to complete our planned sensitivity analyses due to having only three studies in our meta-analysis. We calculated missing data in one of the three studies, which had the largest number of participants, so removing this study likely would have an impact on the findings. Two of the three studies in our meta-analysis had some concerns for bias, and one had low concerns. None of these studies reported statistically significant results. They all favored CSE, but we could not determine whether or not the bias risk had an impact on the results due to the small number of studies.

\section{Secondary Outcomes - STI rates, safe-sex behaviors, sexual activity, and social discomfort}

Twenty-eight studies reported at least one of our secondary outcomes. Twenty-one reported safe-sex behavior outcomes, 24 reported sexual activity outcomes, and three reported STI outcomes. No studies reported outcomes on social discomfort.

STI Rates. None of the three studies reporting this outcome yielded statistically significant results, however, the results all favored CSE. None of the three studies reporting on STI rates had a CSE intervention that emphasized abstinence. Studies with and without an interactive component had results that favored CSE intervention. Many other studies specified objectives directly related to reduction in STIs, but they did not include any results on their prevalence post-intervention.

Safe-Sex Behaviors. Of the 21 studies reporting outcomes related to safe-sex behaviors, $12(57.1 \%)$ reported at least one statistically significant result, favoring CSE (Table 3). The most commonly reported outcomes were related to condom use (15 out of 21 studies). Eight of these 15 studies reported results that were statistically significant in favor of CSE. Of these statistically significant results, the majority were related to consistency and frequency of condom use. Condom use was often the study's primary outcome. Nine studies reported outcomes related to unprotected sex, with four finding that unprotected sex was significantly lower for those who received CSE. Seven studies reported an outcome related to birth control use, and four of these studies found that birth control use was significantly higher in the CSE intervention group. We categorized frequency of STI testing as a safe-sex behavior. The study reporting this outcome did not yield significant results, although it did favor CSE. 
One study used abstinence-only as a comparison group in addition to no intervention.[26] The outcome, "frequency of condom use," was statistically significant when comparing CSE to no intervention, but not to the abstinence-only intervention. Among studies with CSE interventions that emphasized abstinence and reported safe-sex behaviors $(n=6)$, five (83.3\%) reported findings that were statistically significant and in favor of the CSE intervention. The remaining study reported condom use at last sex and did not find a statistically significant difference.[27] For studies of CSE interventions that did not emphasize abstinence $(n=15)$, nine $(60 \%)$ reported positive and statistically significant outcomes. For studies with an interactive CSE intervention and reporting safe-sex behaviors $(n=7)$, six $(85.7 \%)$ reported positive and statistically significant outcomes. Of the remaining studies without an interactive CSE intervention reporting on safe-sex behaviors $(n=14)$, eight $(57.1 \%)$ found a statistically significant difference in favor of the CSE intervention group.

Sexual Activity. Of the 24 studies reporting outcomes related to safe-sex behaviors, eight (33.3\%) reported at least one statistically significant result, favoring CSE (Table 3). The most commonly reported outcomes were related to engaging in any type of sex or sexual behaviors (e.g., ever had sex, frequency of sexual activity, and number of sexual partners), with 17 out of 24 studies reporting outcomes in this category. Six of these 17 studies reported results that were statistically significant, favoring CSE. Of these statistically significant results, the majority were related to ever having sex or the number of sexual partners. These were common primary outcomes as well. Seven studies reported an outcome related specifically to engaging in vaginal sex, with two of these studies reporting statistically significant results in favor of CSE. There were four studies that reported outcomes related to engaging in anal or oral sex specifically, two found that these instances were significantly lower in the CSE intervention group. Four studies reported outcomes related to sexual initiation, three found that sexual initiation was significantly lower for those who received CSE. Finally, three studies reported outcomes related to abstaining from sex, e.g., chose not to have sex under pressure and virginity rates. Only one was statistically significant, favoring CSE, but this was only true for the females in the study. One study had consistently significant results, favoring CSE, for the males in the study but not for the females when looking at ever having sex and having sex in the past 12 months.[28] This was different from other studies that reported separate male and female results and did not see a drastic difference.

Among studies of CSE interventions that emphasized abstinence and reported on sexual activity ( $n=9)$, four (44.4\%) studies reported outcomes that were statistically significant and in favor of the CSE intervention compared to control. There were 15 studies that had CSE interventions that did not emphasize abstinence and reported outcomes on sexual activity. Of these, six (40\%) found a statistically significant difference in favor of the CSE intervention compared to control. Among studies with an interactive CSE that reported on sexual activity $(n=7), 5(71.4 \%)$ reported outcomes with a statistically significant difference in favor of the CSE intervention. There were 17 studies without interactive CSE interventions that reported on sexual activity. Five (29.4\%) found a statistically significant difference in favor of the CSE intervention.

\section{Discussion}

\section{Summary of main findings}

There is sufficient evidence to address the objectives of this review. The data we gathered from RCTs show that adolescents who received CSE were less likely to experience pregnancy and more likely to practice safe-sex behaviors, particularly condom use. The data did not provide evidence for changes in sexual activity or STI incidence. Additionally, the lack of studies measuring pregnancy prevented us from making meaningful conclusions about various CSE delivery methods, race, and sex. Only one included study used abstinence-only education as the comparison condition. Therefore, our results suggest that CSE decreases pregnancy rates and increases condom use when compared to no intervention, as there is insufficient data to make any conclusions regarding CSE compared to an abstinence-only education.

There was heterogeneity in the secondary outcomes reported and CSE interventions across the studies. Additionally, the populations of the included studies were diverse, with respect to race, sex, and setting. Outcomes varied by timeframe and metric, however most were similar enough for us to determine which outcomes were most impacted by CSE. Studies with CSE interventions that emphasized abstinence or were interactive yielded more positive and statistically significant differences in safe-sex behaviors and sexual activity outcomes compared to CSE interventions that did not emphasize abstinence or were not interactive. Too few studies reported pregnancy and STI incidence outcomes to look at results by intervention design. However, the diversity in populations studied, timeframes, and metrics increased the generalizability of our findings.

We were surprised to see so few results on STI rates, as many of the interventions were tailored toward HIV/AIDS reduction or STI reduction in general. Testing for STIs before and after the intervention would be another helpful outcome to measure in the future. Despite no studies reporting outcomes related to social discomfort, many adolescents experience social discomfort when learning about or discussing sexual health topics, as this area is inherently uncomfortable; therefore, the degree of social discomfort that the participants felt could affect their ability to learn from the interventions and impact other outcomes.[29]

\section{Quality of the evidence}

Based on the GRADE assessment tool, the general methodological quality of the included studies is moderate. The methodological quality of included studies with pregnancy, safe-sex behaviors, and STI rates as the primary outcomes was moderate while that of studies with sexual activity as the primary outcome was low. These results did not have a high level of quality.

Both the safe-sex behavior and sexual activity outcomes were similar in certain domains of GRADE. Most studies in both outcomes had a high number of participants, so the publication bias risk was low for both groups. Also, the point estimates for these studies were small, so these studies did not have a large magnitude of effect and had inconsistent findings with differences in these point estimates and confidence intervals. Two studies in both groups addressed the potential effects of residual confounding. Both tools (Cochrane RoB and GRADE) did not assess the presence of detrimental confounding variables in studies, so the levels of methodological quality for each outcome could be lower than the reported levels from the GRADE assessment. 
The prospective registration of our protocol and tracking of changes (Appendix 1) prevented the authors from imposing bias to the results reported. The changes made to the initial protocol did not alter our findings or the overall objective of this review. Our study employed a comprehensive search strategy to identify potentially eligible studies. Each step of our review was double blinded to ensure validity. We used standardized and empirically supported tools to assess risk of bias and methodological quality for each included study. Although our search strategy was comprehensive, we did not search some databases that might have been relevant but did not focus primarily on randomized trials (e.g., CINAHL). While we included referenced protocols and trial registrations, we did not request uncited protocols or missing data from authors. This could have led to undetected publication and reporting bias of included studies due to omitted information. Another potential limitation is that we did not conduct a subgroup analysis between studies that had control groups with an active intervention (e.g., healthy eating intervention) compared to no intervention. The latter studies may have suffered from confounding variables. While the overall results were robust, only three studies were included in our meta-analysis. Statistical significance may have been achieved in our primary outcome if more studies met our eligibility criteria for the meta-analysis.

Agreements and disagreements with other studies or reviews

A prior systematic review published in 2016 analyzed RCTs comparing CSE interventions to no intervention.[30]This review only looked at school-based CSE and studies completed outside the US. In contrast to our review, they found no change in pregnancy or STI prevalence, except for one study that found a decrease in the prevalence of HSV. US-based studies may have different priorities than studies in other regions. We included more outcomes than the prior review, including safe-sex behaviors and sexual activity. These outcomes can be process measures for reducing STI incidence. We did find CSE to be advantageous at increasing safe-sex behaviors, which, although is not a definite conclusion, could be related to a decrease in STIs. Furthermore, state-level data indicates a relationship between CSE and STI rates with lower STI incidence in states where CSE is mandated.

\section{Conclusions}

\section{Implications for practice}

Data from this review can serve as evidence for implementing CSE into schools, homes, or community-based platforms. Future research should look at the impact that race has on the effectiveness of CSE interventions, as many studies that we included had African American-only participants. This group has been studied more often and has been said to be at a higher risk for unintended pregnancy and STIs, so determining whether CSE is more or less effective for this group would be noteable.[31]

Our results fit into the context of current practice by providing evidence and information about the benefits of CSE interventions, which can promote safe-sex behaviors like condom use. We identified that certain features, such as having an interactive intervention, may increase the efficacy of CSE interventions. Also, this review provides evidence for the benefits of teaching adolescents about the harms of unsafe sexual activity. US states without current sexuality education requirements should assess the evidence provided to note the benefits of a policy change regarding implementation of CSE. Additionally, there are potential cost-saving incentives for states mandating CSE based on the results showing improvements in teen pregnancy rates. Adolescent pregnancies cost the US at least $\$ 9.1$ billion annually.[32] There are additional social costs too.[32] Further studies comparing CSE to abstinence-only will be needed before determining whether or not states that require abstinence-only could benefit from a policy change to CSE.

Implications for research

The results and conclusions of this review may be different if additional research had been conducted. When we reviewed articles, we found that some studies did not explicitly explain the control condition and/or describe aspects of the standard sexuality education, so we excluded these. In the future, an RCT comparing CSE to abstinence-only education should be conducted. Most studies we included did not involve this comparison. Also, more studies should be conducted that analyze CSE interventions that are highly effective for at-risk groups (e.g., African American, Hispanic). Furthermore, studies including social discomfort as an outcome could assess to what degree social discomfort could potentially mediate the effectiveness of CSE.

\section{List Of Abbreviations}

Comprehensive Sexuality Education (CSE); Sexually transmitted infections (STI); United States (US); Preferred Reporting Items for Systematic Reviews and Meta-Analyses (PRISMA); Open Science Framework (OSF); Randomized controlled trial (RCT); Grading of Recommendations, Assessment, Development and Evaluations (GRADE); Cochrane risk-of-bias (RoB); Relative risk (RR); Confidence interval (Cl)

\section{Declarations}

Ethics approval and consent to participate

No ethical approval or participation consent was necessary for this report.

Consent for publication

Not applicable.

Availability of data and materials 
Not applicable.

Competing interests

The authors declare no relevant conflicts of interest.

Funding

No funding was received to assist with this review.

\section{Author Contributions}

$A B, A C$, and $A M$ conceptualized the idea for the study. Search methods and data extraction were performed by $A B, A C$, and $R N$. Data analysis was conducted by $A B$ and Risk of Bias analysis was conducted by $A C$ and RN. All authors contributed to the first draft of the manuscript and commented on subsequent manuscript versions. RY, the supervisor, critically revised the work, and all authors read and approved the final manuscript.

Acknowledgements

We thank Paige Scudder, Dr. Rebecca Emeny, and Dr. Rebecca Evans for their help with this review.

\section{References}

1. Sedgh G, Finer LB, Bankole A, Eilers MA, Singh S. Adolescent pregnancy, birth, and abortion rates across countries: levels and recent trends. The Journal of adolescent health: official publication of the Society for Adolescent Medicine. 2015;56(2):223-30.

2. Penman-Aguilar A, Carter M, Snead MC, Kourtis AP. Socioeconomic disadvantage as a social determinant of teen childbearing in the U.S. Public health reports. 2013;128(Suppl 1):5-22.

3. Romero L, Pazol K, Warner L, Cox S, Kroelinger C, Besera G, ... Barfield W. Reduced Disparities in Birth Rates Among Teens Aged 15-19 Years - United States, 2006-2007 and 2013-2014. MMWR Morbidity mortality weekly report. 2016;65(16):409-14.

4. About Teen Pregnancy. (2020, October 28). Retrieved June 15, 2021, from https://www.cdc.gov/teenpregnancy/about/index.htm.

5. Unintended Pregnancy. (2019, September 13). Retrieved June 15, 2021, from https://www.cdc.gov/reproductivehealth/contraception/unintendedpregnancy/index.htm.

6. Sexually transmitted diseases, 40(3), 187-193.

7. Sex, Education HIV. (2016, March 14). Retrieved June 15, 2021, from https://www.guttmacher.org/state-policy/explore/sex-and-hiv-education.

8. The guidelines. (2018, July 11). Retrieved June 15, 2021, from https://siecus.org/resources/the-guidelines/.

9. Kirby D. Emerging Answers: Research Findings on Programs to Reduce Teen Pregnancy. National Campaign to Prevent Teen Pregnancy; 2001.

10. Stanger-Hall KF, Hall DW. Abstinence-only education and teen pregnancy rates: why we need comprehensive sex education in the U.S. PloS one. 2011;6(10):e24658.

11. Alaska State Profile. (2021, March 29). Retrieved June 15, 2021, from https://siecus.org/state_profile/alaska-fy21-state-profile/.

12. Sexually Transmitted Diseases by State. (2019, February 4). Retrieved June 15, 2021, from https://www.alarms.org/std-statistics/.

13. CDC. (2021, January 25). STI prevalence, incidence, and cost estimates infographic. Retrieved June 29, 2021, from https://www.cdc.gov/std/statistics/prevalence-2020-at-a-glance.htm.

14. Moher D, Liberati A, Tetzlaff J, Altman DG, PRISMA Group. Preferred reporting items for systematic reviews and meta-analyses: the PRISMA statement. PLoS Med. 2009;6(7):e1000097.

15. Ouzzani M, Hammady H, Fedorowicz Z, Elmagarmid A. Rayyan-a web and mobile app for systematic reviews. Systematic reviews. 2016;5(1):210.

16. Schünemann H. The GRADE handbook. Cochrane Collaboration; 2013.

17. Journal of clinical epidemiology, 66(2), 151-157.

18. BMJ, 366. https://doi.org/10.1136/bmj.14898

19. Higgins J, Green S, editors. (2011). Cochrane handbook for systematic reviews of interventions (1st ed.). Nashville, TN: John Wiley \& Sons. Retrieved from https://training.cochrane.org/handbook.

20. Review Manager (RevMan) [Computer program]. Version 5.4, The Cochrane Collaboration. 2020. (n.d.).

21. Riley RD, Higgins JPT, Deeks JJ. (2011). Interpretation of random effects meta-analyses. BMJ, 342. https://doi.org/10.1136/bmj.d549.

22. BMJ, 339. https://doi.org/10.1136/bmj.b2700

23. Higgins JPT, Thompson SG. Quantifying heterogeneity in a meta-analysis. Statistics in medicine. 2002;21(11):1539-58.

24. The Journal of adolescent health: official publication of the Society for Adolescent Medicine, 50(3), 279-288.

25. O’Donnell L, Fuxman S. Effectiveness of a Brief Home Parenting Intervention for Reducing Early Sexual Risks Among Latino Adolescents: Salud y Éxito. J Sch Health. 2017;87(11):858-64.

26. Jemmott JB, Jemmott III, L. S., \& Fong GT. Abstinence and Safer Sex HIV Risk-Reduction Interventions for African American Adolescents: A Randomized Controlled Trial. JAMA: the journal of the American Medical Association. 1998;279(19):1529-36. 
27. Kaufman CE, Whitesell NR, Keane EM, Desserich JA, Giago C, Sam A, Mitchell CM. Effectiveness of Circle of Life, an HIV-preventive intervention for American Indian middle school youths: a group randomized trial in a Northern Plains tribe. American journal of public health. 2014;104(6):e106-12.

28. Coyle KK, Kirby DB, Marín BV, Gómez CA, Gregorich SE. Draw the line/respect the line: a randomized trial of a middle school intervention to reduce sexual risk behaviors. American journal of public health. 2004;94(5):843-51.

29. Leung H, Shek DTL, Leung E, Shek EYW. (2019). Development of Contextually-relevant Sexuality Education: Lessons from a Comprehensive Review of Adolescent Sexuality Education Across Cultures. Int J Environ Res Public Health, 16(4). https://doi.org/10.3390/ijerph16040621.

30. Mason-Jones AJ, Sinclair D, Mathews C, Kagee A, Hillman A, Lombard C. School-based interventions for preventing HIV, sexually transmitted infections, and pregnancy in adolescents. Cochrane database of systematic reviews. 2016;11:CD006417.

31. African Americans Disproportionately Affected by STDs. (2019, April 24). Retrieved June 15, 2021, from https://www.cdc.gov/stdconference/2000/media/afamericans2000.htm.

32. Brace AM, Hall M, Hunt BP. Social, Economic and Health Costs of Unintended Teen Pregnancy: The Circle of Care Intervention Program in Troup County, Georgia. Journal of the Georgia Public Health Association. 2008;3(1):33-46.

33. JAMA: the journal of the American Medical Association, 292(2), 171-179.

34. Barbee AP, Cunningham MR, van Zyl MA, Antle BF, Langley CN. Impact of Two Adolescent Pregnancy Prevention Interventions on Risky Sexual Behavior: A Three-Arm Cluster Randomized Control Trial. American journal of public health. 2016;106(S1):85-90.

35. DiClemente RJ, Wingood GM, Rose E, Sales JM, Crosby RA. Evaluation of an HIV/STD sexual risk-reduction intervention for pregnant African American adolescents attending a prenatal clinic in an urban public hospital: preliminary evidence of efficacy. J Pediatr Adolesc Gynecol. 2010;23(1):32-8.

36. Jenner E, Jenner LW, Walsh S, Demby H, Gregory A, Davis E. Impact of an Intervention Designed to Reduce Sexual Health Risk Behaviors of African American Adolescents: Results of a Randomized Controlled Trial. American journal of public health. 2016;106(S1):78-84.

37. Sex education, 11(1), 27-46.

38. Morrison-Beedy D, Jones SH, Xia Y, Tu X, Crean HF, Carey MP. Reducing sexual risk behavior in adolescent girls: results from a randomized controlled trial. The Journal of adolescent health: official publication of the Society for Adolescent Medicine. 2013;52(3):314-21.

39. Kerr DCR, Leve LD, Chamberlain P. Pregnancy rates among juvenile justice girls in two randomized controlled trials of multidimensional treatment foster care. J Consult Clin Psychol. 2009;77(3):588-93.

40. The Journal of adolescent health: official publication of the Society for Adolescent Medicine, 56(5), 515-521.

41. Oman RF, Vesely SK, Green J, Clements-Nolle K, Lu M. Adolescent Pregnancy Prevention Among Youths Living in Group Care Homes: A Cluster Randomized Controlled Trial. American journal of public health. 2018;108(S1):38-44.

42. The Journal of adolescent health: official publication of the Society for Adolescent Medicine, 49(2), 172-179.

43. Tortolero SR, Markham CM, Peskin MF, Shegog R, Addy RC, Escobar-Chaves SL, Baumler ER. It's Your Game: Keep It Real: delaying sexual behavior with an effective middle school program. The Journal of adolescent health: official publication of the Society for Adolescent Medicine. 2010;46(2):169-79.

44. LaChausse RG. A Clustered Randomized Controlled Trial of the Positive Prevention PLUS Adolescent Pregnancy Prevention Program. American journal of public health. 2016;106(S1):91-6.

45. The Journal of adolescent health: official publication of the Society for Adolescent Medicine, 27(4), 236-247.

46. Coyle KK, Kirby DB, Robin LE, Banspach SW, Baumler E, Glassman JR. All4You! A randomized trial of an HIV, other STDs, and pregnancy prevention intervention for alternative school students. AIDS education prevention: official publication of the International Society for AIDS Education.

2006;18(3):187-203.

47. Milhausen RR, DiClemente RJ, Lang DL, Spitalnick JS, McDermott Sales J, Hardin JW. Frequency of sex after an intervention to decrease sexual risktaking among African-American adolescent girls: results of a randomized, controlled clinical trial. Sex education. 2008;8(1):47-57.

48. Sherr ME, Pooler D, Stamey J, Jones J, Dyer P. A randomized effectiveness trial of a sex education program for minority youth in Miami, Florida. J Evid Based Soc Work. 2013;10(2):53-62.

49. Philliber S, Kaye JW, Herrling S, West E. Preventing pregnancy and improving health care access among teenagers: an evaluation of the children's aid society-carrera program. Perspect Sex Reprod Health. 2002;34(5):244-51.

50. Jemmott JB 3rd, Jemmott LS, Fong GT. Reductions in HIV risk-associated sexual behaviors among black male adolescents: effects of an AIDS prevention intervention. American journal of public health. 1992;82(3):372-7.

51. Allen JP, Philliber S, Herrling S, Kuperminc GP. Preventing Teen Pregnancy and Academic Failure: Experimental Evaluation of a Developmentally Based Approach. Child development. 1997;68(4):729-42.

52. Klein $\mathrm{CH}$, Card JJ. Preliminary efficacy of a computer-delivered HIV prevention intervention for African American teenage females. AIDS education prevention: official publication of the International Society for AIDS Education. 2011;23(6):564-76.

53. Walter HJ, Vaughan RD. AIDS risk reduction among a multiethnic sample of urban high school students. JAMA: the journal of the American Medical Association. 1993;270(6):725-30.

54. Scholes D, McBride CM, Grothaus L, Civic D, Ichikawa LE, Fish LJ, Yarnall KS. A tailored minimal self-help intervention to promote condom use in young women: results from a randomized trial. AIDS. 2003;17(10):1547-56.

55. Jemmott JB 3rd, Jemmott LS, Fong GT, Morales KH. Effectiveness of an HIV/STD risk-reduction intervention for adolescents when implemented by community-based organizations: a cluster-randomized controlled trial. American journal of public health. 2010;100(4):720-6. 
56. Jemmott JB 3rd, Jemmott LS, Braverman PK, Fong GT. HIV/STD risk reduction interventions for African American and Latino adolescent girls at an adolescent medicine clinic: a randomized controlled trial. Arch Pediatr Adolesc Med. 2005;159(5):440-9.

57. Protect our children! (n.d.). Retrieved June 16, 2021, from https://www.comprehensivesexualityeducation.org/.

\section{Tables}

Table 1. Characteristics of included studies 


\begin{tabular}{|c|c|c|c|c|c|c|c|c|}
\hline $\begin{array}{l}\text { First author last } \\
\text { name, year of } \\
\text { publication }\end{array}$ & Study period & Age range & $\begin{array}{l}\text { Race/ } \\
\text { ethnicity (\%) }\end{array}$ & Gender (\%) & $\begin{array}{l}\text { Intervention } \\
\text { delivery } \\
\text { method }\end{array}$ & Comparator & $\begin{array}{l}\text { Number } \\
\text { enrolled }\end{array}$ & $\begin{array}{l}\text { Number } \\
\text { analyzed }\end{array}$ \\
\hline $\begin{array}{l}\text { DiClemente, } \\
2004[33]\end{array}$ & $\begin{array}{l}\text { September } \\
1995- \\
\text { August } \\
2002\end{array}$ & $14-18$ & $\begin{array}{l}\text { African American: } \\
100 \%\end{array}$ & $\begin{array}{l}\text { Female: } \\
100 \%\end{array}$ & $\begin{array}{l}\text { Other } \\
\text { (specify)* }^{*}\end{array}$ & No intervention & 1130 & 460 \\
\hline Barbee, $2016[34]$ & $\begin{array}{l}\text { September } \\
2011-\text { March } \\
2014\end{array}$ & $14-19$ & $\begin{array}{l}\text { Non-Hispanic white: } \\
\sim 7 \% \\
\text { Non-Hispanic Black: } \\
\sim 88 \% \\
\text { Hispanic: } \sim 3 \% \\
\text { Asian } \sim 0.3 \%\end{array}$ & $\begin{array}{l}\text { Female: } \\
\sim 63 \%\end{array}$ & $\begin{array}{l}\text { Other } \\
(\text { specify)* }\end{array}$ & No intervention & 1448 & 1378 \\
\hline $\begin{array}{l}\text { DiClemente, } \\
2010 \text { [35] }\end{array}$ & $\begin{array}{l}\text { April 1999- } \\
\text { June } 2000\end{array}$ & $14-20$ & $\begin{array}{l}\text { African American: } \\
100 \%\end{array}$ & $\begin{array}{l}\text { Female: } \\
100 \%\end{array}$ & $\begin{array}{l}\text { Other } \\
(\text { specify)* }\end{array}$ & No intervention & 170 & 86 \\
\hline Jenner, $2016[36]$ & $2012-2014$ & $14-18$ & $\begin{array}{l}\text { Intervention/Control: } \\
\text { African American: } \\
84.8 \% / 82.66 \%\end{array}$ & $\begin{array}{l}\text { Intervention: } \\
\text { Female: } \\
52.63 \% \\
\text { Control: } \\
\text { Female: } \\
52.6 \%\end{array}$ & $\begin{array}{l}\text { Other } \\
\text { (specify)* }^{*}\end{array}$ & No intervention & 850 & 688 \\
\hline $\begin{array}{l}\text { Jemmott, } \\
1998[26]\end{array}$ & NR & Mean: 11.8 & $\begin{array}{l}\text { African American: } \\
100 \%\end{array}$ & Female: 53\% & $\begin{array}{l}\text { School- } \\
\text { based CSE }\end{array}$ & $\begin{array}{l}\text { Abstinence } \\
\text { only and No } \\
\text { Intervention }\end{array}$ & NR & 610 \\
\hline Koo, 2011 [37] & $2001-2003$ & $\begin{array}{l}\text { Fifth- } \\
\text { sixth grade }\end{array}$ & African American: 99\% & Female: $54 \%$ & $\begin{array}{l}\text { School- } \\
\text { based CSE }\end{array}$ & No intervention & NR & 928 \\
\hline $\begin{array}{l}\text { Markham, } \\
2012[24]\end{array}$ & 2006-2010 & $\begin{array}{l}\text { Mean } \\
(\mathrm{SD}): 12.6 \\
(0.76)\end{array}$ & $\begin{array}{l}\text { African American: } \\
39.3 \% \\
\text { Hispanic: } 48.4 \% \\
\text { Other } 12.2 \%\end{array}$ & $\begin{array}{l}\text { Female: } \\
59.8 \%\end{array}$ & $\begin{array}{l}\text { School- } \\
\text { based CSE }\end{array}$ & No intervention & 1742 & 794 \\
\hline $\begin{array}{l}\text { Morrison-Beedy, } \\
2013 \text { [38] }\end{array}$ & $\begin{array}{l}\text { December } \\
2004- \\
\text { August } \\
2009\end{array}$ & $15-19$ & $\begin{array}{l}\text { Black/African } \\
\text { American: } 69 \% \\
\text { White/Caucasian: } 9 \% \\
\text { Mixed/multiracial: } 11 \% \\
\text { Other: } 11 \%\end{array}$ & Girls: $100 \%$ & $\begin{array}{l}\text { Other } \\
\text { (specify)* }\end{array}$ & No intervention & 738 & 484 \\
\hline $\begin{array}{l}\text { O'Donnell, } \\
2017 \text { [25] }\end{array}$ & $2010-2014$ & Mean: 11.7 & Latino: $100 \%$ & $\begin{array}{l}\text { Female: } \\
52.6 \%\end{array}$ & $\begin{array}{l}\text { Home-based } \\
\text { CSE }\end{array}$ & No intervention & 2621 & 3283 \\
\hline Kerr, 2009 [39] & 1997-2006 & $13-17$ & $\begin{array}{l}\text { Caucasian: } 74 \% \\
\text { African American: } 2 \% \\
\text { Hispanic: } 7 \% \\
\text { Native American: } 4 \% \\
\text { Asian: } 1 \% \\
\text { Mixed ethnic heritage: } \\
13 \%\end{array}$ & $\begin{array}{l}\text { Female: } \\
100 \%\end{array}$ & $\begin{array}{l}\text { Other } \\
(\text { specify)* }\end{array}$ & No intervention & 85 & 83 \\
\hline Peskin, 2015[40] & NR & $\begin{array}{l}\text { Mean } \\
\text { (SD): } \\
14.32(0.59)\end{array}$ & $\begin{array}{l}\text { Hispanic: } 74 \% \\
\text { African American: 17\% } \\
\text { Other: } 9 \%\end{array}$ & Female: 59\% & $\begin{array}{l}\text { Other } \\
\text { (specify)* }\end{array}$ & No intervention & 4718 & 1374 \\
\hline Oman, 2018 [41] & 2012-2014 & $13-18$ & $\begin{array}{l}\text { Non-Hispanic White: } \\
20.6 \% \\
\text { Hispanic: } 36.8 \% \\
\text { Non-Hispanic Black: } \\
20.0 \% \\
\text { Non-Hispanic Asian or } \\
\text { Pacific Islander: } 1.6 \% \\
\text { Non-Hispanic Native } \\
\text { American/Alaska } \\
\text { Native: 3.8\% } \\
\text { Non-Hispanic } \\
\text { multiracial: } 17.2 \%\end{array}$ & Male: $79 \%$ & $\begin{array}{l}\text { Other } \\
\text { (specify)* }\end{array}$ & No intervention & 1037 & 881 \\
\hline Sieving, 2011 [42] & $\begin{array}{l}\text { April 2007- } \\
\text { October } \\
2008\end{array}$ & $13-17$ & $\begin{array}{l}\text { Intervention/Control: } \\
\text { American } \\
\text { Indian/Native } \\
\text { American: } 3 \% / 2 \% \\
\text { Asian/Asian } \\
\text { American/Pacific } \\
\text { Islander: } 10 \% / 13 \%\end{array}$ & $\begin{array}{l}\text { Female: } \\
100 \%\end{array}$ & $\begin{array}{l}\text { Other } \\
\text { (specify)* }\end{array}$ & No intervention & 253 & 239 \\
\hline
\end{tabular}




\begin{tabular}{|c|c|c|c|c|c|c|c|c|}
\hline & & & $\begin{array}{l}\text { Black/African/African } \\
\text { American: 45\%/38\% } \\
\text { Hispanic /Latina: } \\
17 \% / 8 \% \\
\text { White/European } \\
\text { American: 6\%/16\% } \\
\text { Mixed/Multiple: } \\
\text { 19\%/23\% }\end{array}$ & & & & & \\
\hline $\begin{array}{l}\text { Tortolero, } \\
2010[43]\end{array}$ & 2004-2007 & $\begin{array}{l}\text { 7th grade- } \\
\text { 9th grade. } \\
\text { Mean: } \\
13.0\end{array}$ & $\begin{array}{l}\text { African American: } \\
42.3 \% \\
\text { Hispanic: } 44 \% \\
\text { Other: } 13.7 \%\end{array}$ & $\begin{array}{l}\text { Female: } \\
59.1 \%\end{array}$ & $\begin{array}{l}\text { School- } \\
\text { based CSE }\end{array}$ & No intervention & 1445 & 907 \\
\hline $\begin{array}{l}\text { LaChausse, } \\
2016[44]\end{array}$ & \begin{tabular}{|l|} 
October \\
2013-May \\
2014
\end{tabular} & $\begin{array}{l}\text { Mean } \\
\text { (SD): } \\
\text { Intervention: } \\
14.63 \\
(0.50) \\
\\
\text { Control: } \\
14.63 \\
(0.48)\end{array}$ & $\begin{array}{l}\text { Intervention/Control: } \\
\text { White: } 0.34 / 0.38 \\
\text { Black: } 0.18 / 0.18 \\
\text { Asian: } 0.08 / 0.09\end{array}$ & $\begin{array}{l}\text { Intervention: } \\
\text { Female: } \\
0.52 \\
\text { Control: } \\
\text { Female: } \\
0.56\end{array}$ & $\begin{array}{l}\text { School- } \\
\text { based CSE }\end{array}$ & No intervention & 4267 & 3490 \\
\hline $\begin{array}{l}\text { Kaufman, } \\
2014[27]\end{array}$ & 2006-2007 & $10-12$ & $\begin{array}{l}\text { American Indian and } \\
\text { Alaska Native: } 100 \%\end{array}$ & $\begin{array}{l}\text { Intervention: } \\
\text { Female: } \\
48.79 \% \\
\text { Control: } \\
\text { Female: } \\
45.17 \%\end{array}$ & $\begin{array}{l}\text { School- } \\
\text { based CSE }\end{array}$ & No intervention & NR & 635 \\
\hline Aarons, 2000[45] & $\begin{array}{l}\text { February } \\
\text { 1996-May } \\
1997\end{array}$ & $\begin{array}{l}\text { 7th-8th } \\
\text { graders }\end{array}$ & $\begin{array}{l}\text { Females/Males:: } \\
\text { African American: } \\
84.7 \% / 82.3 \% \\
\text { Hispanic: } \\
12.0 \% / 14.1 \% \\
\text { Other: } 1.8 \% / 1.2 \%\end{array}$ & $\begin{array}{l}\text { Female: } 274 \\
\text { (of 522) }\end{array}$ & $\begin{array}{l}\text { School- } \\
\text { based CSE }\end{array}$ & No intervention & 582 & 422 \\
\hline Coyle, 2006[46] & $2000-2001$ & NR & $\begin{array}{l}\text { Intervention/Control: } \\
\text { African American: } \\
\text { 29.0\%/25.8\% } \\
\text { Asian American: } \\
16.9 \% / 12.8 \% \\
\text { Hispanic/Latino: } \\
27.6 \% / 31.5 \% \\
\text { White: } 12.2 \% / 12.3 \% \\
\text { Other or multi-ethnic: } \\
\text { 14.2\%/17.6\% }\end{array}$ & $\begin{array}{l}\text { Intervention: } \\
\text { Male: } \\
61.2 \% \\
\text { Female: } \\
38.8 \% \\
\\
\text { Control: } \\
\text { Male: } \\
65.0 \% \\
\text { Female: } \\
35.0 \%\end{array}$ & $\begin{array}{l}\text { School- } \\
\text { based CSE }\end{array}$ & No intervention & 988 & 308 \\
\hline $\begin{array}{l}\text { Milhausen, } \\
\text { 2008[47] }\end{array}$ & $\begin{array}{l}\text { December } \\
\text { 1996-April } \\
1999\end{array}$ & $14-19$ & $\begin{array}{l}\text { African American: } \\
100 \%\end{array}$ & $\begin{array}{l}\text { Female: } \\
100 \%\end{array}$ & $\begin{array}{l}\text { Other } \\
\text { (specify)* }\end{array}$ & No intervention & 522 & 460 \\
\hline Sherr, 2013[48] & NR & $13-17$ & $\begin{array}{l}\text { Intervention/Control: } \\
\text { Black: } 20.8 \% / 26.8 \% \\
\text { Hispanic: } \\
72.1 \% / 68.4 \% \\
\text { White and other: } \\
7.1 \% / 7.8 \%\end{array}$ & $\begin{array}{l}\text { Intervention: } \\
\text { Girl: } 52.0 \% \\
\text { Boy: } 48.0 \% \\
\text { Control: } \\
\text { Girl: } 59.1 \% \\
\text { Boy: } 40.9 \%\end{array}$ & $\begin{array}{l}\text { School- } \\
\text { based CSE }\end{array}$ & No intervention & 973 & 966 \\
\hline $\begin{array}{l}\text { Philliber, } \\
2002[49]\end{array}$ & NR & $13-15$ & $\begin{array}{l}\text { Intervention/Control: } \\
\text { Black: } 60 \% / 52 \% \\
\text { Hispanic: } 39 \% / 45 \% \\
\text { Other: } 1 \% / 3 \%\end{array}$ & $\begin{array}{l}\text { Female: } \\
55.4 \% \\
\text { Male: } 44.6 \%\end{array}$ & $\begin{array}{l}\text { Other } \\
\text { (specify)* }\end{array}$ & No intervention & 600 & 484 \\
\hline $\begin{array}{l}\text { Jemmott, } \\
1992[50]\end{array}$ & \begin{tabular}{|l} 
October \\
$1988-$ \\
January \\
1999
\end{tabular} & Mean: 14.64 & Black: $100 \%$ & Male: $100 \%$ & $\begin{array}{l}\text { Other } \\
\text { (specify)* }\end{array}$ & No intervention & NR & 157 \\
\hline Allen, 1997[51] & 1995-1995 & $\begin{array}{l}\text { 9-12th } \\
\text { grade }\end{array}$ & $\begin{array}{l}\text { Intervention/Control: } \\
\text { Black: } 67.7 \% / 66.6 \% \\
\text { White: } 17.0 \% / 20.4 \% \\
\text { Hispanic: } 12.9 \% / 9.6 \% \\
\text { Other: } 2.4 \% / 3.4 \%\end{array}$ & $\begin{array}{l}\text { Intervention: } \\
\text { Females: } \\
86 \% \\
\text { Males: } 14 \% \\
\text { Control: } \\
\text { Females: } \\
83.3 \% \\
\text { Males: } \\
16.7 \%\end{array}$ & $\begin{array}{l}\text { School- } \\
\text { based CSE }\end{array}$ & No intervention & NR & NR \\
\hline
\end{tabular}




\begin{tabular}{|c|c|c|c|c|c|c|c|c|}
\hline Klein, 2011[52] & NR & $14-18$ & $\begin{array}{l}\text { African American: } \\
100 \%\end{array}$ & $\begin{array}{l}\text { Female: } \\
100 \%\end{array}$ & Virtual CSE & No intervention & 178 & 162 \\
\hline Walter, 1993[53] & 1990-1991 & $12-20$ & $\begin{array}{l}\text { Black: } 36.7 \% \\
\text { Hispanic: } 35.4 \% \\
\text { Other: } 27.9 \%\end{array}$ & Male: $41.5 \%$ & $\begin{array}{l}\text { School- } \\
\text { based CSE }\end{array}$ & No intervention & NR & 1201 \\
\hline $\begin{array}{l}\text { Scholes, } \\
2003[54]\end{array}$ & $\begin{array}{l}\text { June 1999- } \\
\text { April } 2000\end{array}$ & $18-24$ & $\begin{array}{l}\text { White: } 69 \% \\
\text { Black: } 19 \% \\
\text { Other: } 12 \%\end{array}$ & $\begin{array}{l}\text { Female: } \\
100 \%\end{array}$ & $\begin{array}{l}\text { Other } \\
\text { (specify)* }\end{array}$ & No intervention & 1210 & 1046 \\
\hline Coyle, 2004[28] & 1997-1999 & Mean: 11.5 & $\begin{array}{l}\text { African American: } \\
5.2 \% \\
\text { Asian: } 15.9 \% \\
\text { Latino: } 59.3 \% \\
\text { White: } 16.5 \% \\
\text { Other: } 3.1 \%\end{array}$ & $\begin{array}{l}\text { Female: } \\
50.1 \%\end{array}$ & $\begin{array}{l}\text { School- } \\
\text { based CSE }\end{array}$ & No intervention & 2829 & NR \\
\hline $\begin{array}{l}\text { Jemmott, } \\
2010[55]\end{array}$ & $\begin{array}{l}\text { February } \\
1998- \\
\text { February } \\
2002\end{array}$ & $13-18$ & $\begin{array}{l}\text { Black or African } \\
\text { American: } 89.9 \%\end{array}$ & $\begin{array}{l}\text { Female: } \\
56.2 \%\end{array}$ & $\begin{array}{l}\text { Other } \\
\text { (specify)* }\end{array}$ & No intervention & 3445 & 1707 \\
\hline $\begin{array}{l}\text { Jemmott, } \\
2005[56]\end{array}$ & NR & $12-19$ & $\begin{array}{l}\text { African American: } \\
463 / 682 \\
\text { Hispanic: } 219 / 682\end{array}$ & $\begin{array}{l}\text { Female: } \\
100 \%\end{array}$ & $\begin{array}{l}\text { Other } \\
\text { (specify)* }\end{array}$ & No intervention & 682 & 682 \\
\hline
\end{tabular}

Abbreviations: NR (Not Reported); CSE (Comprehensive Sex Education); SD (Standard Deviation)

*See Appendix 5 for additional information on intervention delivery method

Table 2. Summary of pregnancy outcome for adolescents provided with a comprehensive sexuality education versus an abstinence-only education or no sexuality education.

\begin{tabular}{|c|c|c|c|c|c|c|c|c|c|}
\hline \multirow[b]{2}{*}{$\begin{array}{l}\text { First author } \\
\text { last name, } \\
\text { year }\end{array}$} & \multirow[b]{2}{*}{$\begin{array}{l}\text { Authors' description of } \\
\text { outcome }\end{array}$} & \multirow[b]{2}{*}{$\begin{array}{l}\text { Length } \\
\text { of } \\
\text { follow- } \\
\text { up }\end{array}$} & \multicolumn{3}{|c|}{ CSE } & \multicolumn{3}{|c|}{ Abstinence-only or no intervention } & \multirow{2}{*}{$\begin{array}{c}\text { Difference } \\
\text { between } \\
\text { groups }\end{array}$} \\
\hline & & & $\begin{array}{l}\text { Baseline } \\
\mathrm{n}(\%) \text { or } \\
\text { mean } \\
(\mathrm{SD})\end{array}$ & $\begin{array}{l}\text { Endpoint } \mathrm{n}(\%) \\
\text { or mean } \\
(\mathrm{SD})\end{array}$ & Change & $\begin{array}{l}\text { Baseline } \mathrm{n}(\%) \\
\text { or mean } \\
(\mathrm{SD})\end{array}$ & $\begin{array}{l}\text { Endpoint } \mathrm{n}(\%) \\
\text { or mean } \\
\text { (SD) }\end{array}$ & Change & \\
\hline Kerr, 2009 & Pregnancy since baseline. & $\begin{array}{l}12 \\
\text { months }\end{array}$ & 0 & $\begin{array}{l}\begin{array}{l}9.1 \% \\
\text { (of } 44)\end{array} \\
\end{array}$ & $\mathrm{N} / \mathrm{A}$ & 0 & $\begin{array}{l}17.9 \% \\
\text { (of 39) }\end{array}$ & N/A & NR \\
\hline Oman, 2018 & $\begin{array}{l}\text { Ever been or gotten } \\
\text { someone pregnant }\end{array}$ & $\begin{array}{l}12 \\
\text { months }\end{array}$ & $\begin{array}{l}177 \\
(34.6 \%)\end{array}$ & $\begin{array}{l}220 \\
(50.5 \%)\end{array}$ & NR & $\begin{array}{l}185 \\
(36.4 \%)\end{array}$ & $\begin{array}{l}250 \\
(56.2 \%)\end{array}$ & NR & $\begin{array}{l}\text { AOR: } 0.67 \\
\text { (95\%CI } \\
0.46-0.99)\end{array}$ \\
\hline $\begin{array}{l}\text { DiClemente, } \\
2010\end{array}$ & $\begin{array}{l}\text { Self- } \\
\text { reported pregnancy }\end{array}$ & $\begin{array}{l}12 \\
\text { months }\end{array}$ & NR & $6.00 \%$ & NR & NR & $8.50 \%$ & NR & $\begin{array}{l}\text { AOR: } 0.74 \\
(\mathrm{P}=0.52 \\
95 \% \mathrm{CI} \\
0.30-1.82)\end{array}$ \\
\hline $\begin{array}{l}\text { LaChausse, } \\
2016\end{array}$ & $\begin{array}{l}\text { Ever been pregnant or } \\
\text { gotten someone pregnant }\end{array}$ & $\begin{array}{l}6 \\
\text { months }\end{array}$ & $0.60 \%$ & $\begin{array}{l}0.02 \\
(0.12)\end{array}$ & NR & $0.60 \%$ & $\begin{array}{l}0.03 \\
(0.16)\end{array}$ & NR & $\begin{array}{l}\text { Mean } \\
\text { difference: } \\
-0.01 \\
(\mathrm{P}=0.07)\end{array}$ \\
\hline Coyle, 2006 & $\begin{array}{l}\text { Pregnancy since baseline } \\
\text { (among sub-sample } \\
\text { reporting sexual activity } \\
\text { previous } 3 \text { months) }\end{array}$ & $\begin{array}{l}12 \\
\text { months }\end{array}$ & NR & NR & NR & NR & NR & NR & $\begin{array}{l}\text { OR: } 1.15 \\
(\mathrm{P}=0.66)\end{array}$ \\
\hline $\begin{array}{l}\text { Philliber, } \\
2002\end{array}$ & $\begin{array}{l}\text { Became pregnant or } \\
\text { caused pregnancy }\end{array}$ & 3 years & NR & 10 & NR & NR & 17 & NR & $P<0.05$ \\
\hline Allen, 1997 & Pregnancy (ever) & $\begin{array}{l}9 \\
\text { months }\end{array}$ & $6.10 \%$ & $4.20 \%$ & NR & $10 \%$ & $9.8 \%$ & NR & $\mathrm{P}<0.05$ \\
\hline
\end{tabular}

Abbreviations: CSE (Comprehensive Sexuality Education); N (Number); SD (Standard Deviation); CI (Confidence Interval); N/A (Not Applicable); NR (Not Reported); AOR (Adjusted Odds Ratio); OR (Odds Ratio) 
Table 3. Summary of secondary outcomes for adolescents provided with a comprehensive sexuality education versus an abstinence-only education or no sexuality education.

Page 14/26 


\begin{tabular}{|c|c|c|c|c|c|c|c|c|c|}
\hline \multirow[b]{2}{*}{$\begin{array}{l}\text { First author } \\
\text { last name, } \\
\text { year }\end{array}$} & \multirow[b]{2}{*}{$\begin{array}{l}\text { Authors' } \\
\text { description of } \\
\text { outcome }\end{array}$} & \multirow[b]{2}{*}{$\begin{array}{l}\text { Length } \\
\text { of } \\
\text { follow- } \\
\text { up }\end{array}$} & \multicolumn{3}{|c|}{ CSE } & \multicolumn{3}{|c|}{$\begin{array}{c}\text { Abstinence-only or no } \\
\text { intervention }\end{array}$} & \multirow{2}{*}{$\begin{array}{l}\text { Difference } \\
\text { between } \\
\text { groups }\end{array}$} \\
\hline & & & $\begin{array}{l}\text { Baseline } \\
\mathrm{n}(\%) \text { or mean } \\
\text { (SD) }\end{array}$ & $\begin{array}{l}\text { Endpoint } \\
\mathrm{n}(\%) \text { or mean } \\
\text { (SD) }\end{array}$ & Change & $\begin{array}{l}\text { Baseline } \\
\mathrm{n}(\%) \text { or } \\
\text { mean } \\
(\mathrm{SD})\end{array}$ & \begin{tabular}{|l|} 
Endpoint \\
$\mathrm{n}(\%)$ or \\
mean \\
$(\mathrm{SD})$
\end{tabular} & Change & \\
\hline \multicolumn{10}{|c|}{ Safe-sex behaviors } \\
\hline \multirow[t]{8}{*}{$\begin{array}{l}\text { DiClemente, } \\
2004\end{array}$} & $\begin{array}{l}\text { Consistent } \\
\text { condom use in } \\
\text { last } 30 \text { days }\end{array}$ & $\begin{array}{l}12 \\
\text { months }\end{array}$ & $\begin{array}{l}60 \\
(40.3)\end{array}$ & $73.30 \%$ & NR & $\begin{array}{l}75 \\
(43.4)\end{array}$ & $56.50 \%$ & NR & $\begin{array}{l}\text { AOR: } 2.23 \\
(\mathrm{P}=0.02 \\
95 \% \mathrm{CI} 1.17- \\
4.27)\end{array}$ \\
\hline & $\begin{array}{l}\text { Consistent } \\
\text { condom use in } \\
\text { last } 6 \text { months }\end{array}$ & $\begin{array}{l}12 \\
\text { months }\end{array}$ & $\begin{array}{c}101 \\
(43.5)\end{array}$ & $58.10 \%$ & NR & $\begin{array}{l}119 \\
(48.6)\end{array}$ & $45.30 \%$ & NR & $\begin{array}{l}\text { AOR: } 2.14 \\
(\mathrm{P}=0.01 \\
95 \% \mathrm{CI} 1.20- \\
3.84)\end{array}$ \\
\hline & $\begin{array}{l}\text { Condom use } \\
\text { during last sex }\end{array}$ & $\begin{array}{l}12 \\
\text { months }\end{array}$ & $\begin{array}{l}74 \\
(31.9)\end{array}$ & $72.30 \%$ & NR & $\begin{array}{l}79 \\
(32.1)\end{array}$ & $53.90 \%$ & NR & $\begin{array}{l}\text { AOR: } 3.32 \\
(\mathrm{P}<0.001 \\
95 \% \mathrm{CI} 1.86- \\
5.92)\end{array}$ \\
\hline & $\begin{array}{l}\text { Percent that } \\
\text { used condom in } \\
\text { past } 30 \text { days }\end{array}$ & \begin{tabular}{|l|}
12 \\
months
\end{tabular} & $\begin{array}{l}79.23 \\
(38)\end{array}$ & $\begin{array}{l}79.97 \\
(36.64)\end{array}$ & NR & $77.47(38)$ & $\begin{array}{l}62.82 \\
(45.28)\end{array}$ & NR & \begin{tabular}{|l} 
Mean \\
difference: \\
21.09 \\
$(\mathrm{P}<0.001$ \\
$95 \%$ CI 10.73- \\
$32.20)$
\end{tabular} \\
\hline & $\begin{array}{l}\text { Percent that } \\
\text { used condom in } \\
\text { past } 6 \text { months }\end{array}$ & $\begin{array}{l}12 \\
\text { months }\end{array}$ & $\begin{array}{l}72.44 \\
(37)\end{array}$ & \begin{tabular}{|l}
73.49 \\
$(37.86)$
\end{tabular} & NR & $70.38(38)$ & $\begin{array}{l}57.58 \\
(43.21)\end{array}$ & NR & $\begin{array}{l}\text { Mean } \\
\text { difference: } \\
18.33 \\
(\mathrm{P}=0.001 \\
95 \% \mathrm{CI} 9.46- \\
29.86)\end{array}$ \\
\hline & $\begin{array}{l}\text { Episodes of } \\
\text { unprotected } \\
\text { vaginal sex in } \\
\text { last } 30 \text { days }\end{array}$ & $\begin{array}{l}12 \\
\text { months }\end{array}$ & $\begin{array}{l}1.12 \\
(2.84)\end{array}$ & $\begin{array}{l}1.15 \\
(3.03)\end{array}$ & NR & $\begin{array}{l}0.84 \\
(2.01)\end{array}$ & \begin{tabular}{|l|}
2.04 \\
$(4.47)$
\end{tabular} & NR & \begin{tabular}{|l} 
Mean \\
difference: \\
-1.06 \\
$(\mathrm{P}=0.002$ \\
$95 \% \mathrm{CI}-1.86-$ \\
$-0.44)$
\end{tabular} \\
\hline & $\begin{array}{l}\text { Episodes of } \\
\text { unprotected } \\
\text { vaginal sex in } \\
\text { last } 6 \text { months }\end{array}$ & \begin{tabular}{|l|}
12 \\
months
\end{tabular} & $\begin{array}{l}4.81 \\
(16.01)\end{array}$ & $\begin{array}{l}5.77 \\
(16.41)\end{array}$ & NR & $\begin{array}{l}4.23 \\
(10.25)\end{array}$ & $\begin{array}{l}10.25 \\
(24.66)\end{array}$ & NR & \begin{tabular}{|l} 
Mean \\
difference: \\
-5.51 (P=0.02, \\
$95 \%$ CI -11.18- \\
$-0.34)$
\end{tabular} \\
\hline & $\begin{array}{l}\text { Frequency of } \\
\text { applying } \\
\text { condoms on sex } \\
\text { partner }\end{array}$ & \begin{tabular}{|l|}
12 \\
months
\end{tabular} & NR & $\begin{array}{l}1.97 \\
(1.28)\end{array}$ & NR & NR & $\begin{array}{l}1.59 \\
(1.09)\end{array}$ & NR & $\begin{array}{l}\text { Mean } \\
\text { difference: } \\
0.44 \\
(\mathrm{P}=0.003, \\
95 \% \mathrm{CI} 0.19 \text { - } \\
0.77)\end{array}$ \\
\hline \multirow[t]{2}{*}{$\begin{array}{l}\text { Barbee, } \\
2016\end{array}$} & $\begin{array}{l}\text { Sex without } \\
\text { condom in past } \\
3 \text { months }\end{array}$ & \begin{tabular}{|l|}
6 \\
months
\end{tabular} & \begin{tabular}{|c} 
RTR: 317 \\
$(13.56 \%)$ \\
\\
LN: 320 \\
$(12.81 \%)$
\end{tabular} & $\begin{array}{c}\text { RTR: } 317 \\
(12.30 \%) \\
\\
\text { LN: } 320 \\
(9.70 \%)\end{array}$ & NR & $\begin{array}{l}13.79 \% \text { of } \\
290\end{array}$ & $\begin{array}{l}16.6 \% \text { of } \\
290\end{array}$ & NR & $\begin{array}{l}\text { RTR: } P=0.08 \\
\text { LN: } P=0.007\end{array}$ \\
\hline & $\begin{array}{l}\text { Sex without } \\
\text { birth control }\end{array}$ & $\begin{array}{l}6 \\
\text { months }\end{array}$ & $\begin{array}{l}\text { RTR: } 317 \\
(11.04 \%) \\
\\
\text { LN: } 313 \\
(11.18 \%)\end{array}$ & $\begin{array}{c}\text { RTR: } 317 \\
(9.10 \%) \\
\\
\text { LN: } 313 \\
(8.30 \%)\end{array}$ & NR & $\begin{array}{l}12.24 \% \\
\text { (of } 286 \text { ) }\end{array}$ & $\begin{array}{l}17.5 \% \\
\text { (of } 286 \text { ) }\end{array}$ & NR & $\begin{array}{l}\text { RTR: } P=0.005 \\
\text { LN: } P=0.001\end{array}$ \\
\hline \multirow[t]{2}{*}{$\begin{array}{l}\text { DiClemente, } \\
2010\end{array}$} & $\begin{array}{l}\text { Condom use at } \\
\text { last intercourse }\end{array}$ & \begin{tabular}{|l|}
$6-9$ \\
months
\end{tabular} & $28.40 \%$ & NR & NR & $28.20 \%$ & NR & NR & $\begin{array}{l}\text { AOR: } 3.9 \\
(\mathrm{P}=0.05, \\
95 \% \mathrm{CI} 1.00- \\
15.71)\end{array}$ \\
\hline & $\begin{array}{l}\text { Consistent } \\
\text { condom use } \\
\text { over the past } 30 \\
\text { days }\end{array}$ & \begin{tabular}{|l|}
$6-9$ \\
months
\end{tabular} & NR & NR & NR & NR & NR & NR & $\begin{array}{l}\text { AOR: } 7.9 \\
(\mathrm{P}=0.05 \\
95 \% \mathrm{CI} 1.00- \\
56.7)\end{array}$ \\
\hline Jenner, & Inconsistency of & 6 & $10.40 \%$ & Mean: 9.05 & NR & $12.79 \%$ & Mean: & NR & Mean \\
\hline
\end{tabular}




\begin{tabular}{|c|c|c|c|c|c|c|c|c|c|}
\hline 2016 & condom use & months & $\begin{array}{l}\text { (SD: } \\
25.57)\end{array}$ & & & $\begin{array}{l}\text { (SD: } \\
27.14)\end{array}$ & 6.74 & & $\begin{array}{l}\text { difference } \\
(\mathrm{SD}): 2.31 \\
(1.80, \mathrm{P}=0.2)\end{array}$ \\
\hline \multirow[t]{4}{*}{$\begin{array}{l}\text { Jemmott, } \\
1998\end{array}$} & $\begin{array}{l}\text { Reporting } \\
\text { consistent } \\
\text { condom use }\end{array}$ & \begin{tabular}{|l|}
12 \\
months
\end{tabular} & NR & $\begin{array}{l}20 \\
(62.5 \%)\end{array}$ & NR & NR & $\begin{array}{l}\text { AO:: } 14 \\
(41.2 \%) \\
\text { NI: } 21 \\
(51.2 \%)\end{array}$ & NR & $\begin{array}{l}\mathrm{AO}: \mathrm{P}=0.09 \\
\mathrm{NO}: \mathrm{P}=0.35\end{array}$ \\
\hline & $\begin{array}{l}\text { Frequency of } \\
\text { condom use }\end{array}$ & \begin{tabular}{|l|}
12 \\
months
\end{tabular} & NR & $\begin{array}{l}4.15 \\
(1.21)\end{array}$ & NR & NR & $\begin{array}{l}\text { AO: } 3.94 \\
(1.28) \\
\text { NO: } 3.16 \\
(1.69)\end{array}$ & NR & $\begin{array}{l}\mathrm{AO}: \mathrm{P}=0.55 \\
\mathrm{NO}: \mathrm{P}=0.004\end{array}$ \\
\hline & $\begin{array}{l}\text { Frequency of } \\
\text { unprotected } \\
\text { sexual } \\
\text { intercourse }\end{array}$ & $\begin{array}{l}12 \\
\text { months }\end{array}$ & NR & $\begin{array}{l}0.17 \\
(2.26)\end{array}$ & $\mathrm{NR}$ & NR & $\begin{array}{l}\text { AO: } 0.29 \\
(2.25) \\
\text { NO: } 0.51 \\
(2.26)\end{array}$ & NR & $\begin{array}{l}\mathrm{AO}: \mathrm{P}=0.17 \\
\mathrm{NI}: \mathrm{P}=0.13\end{array}$ \\
\hline & $\begin{array}{l}\text { Percent } \\
\text { reporting } \\
\text { unprotected } \\
\text { sexual } \\
\text { intercourse }\end{array}$ & \begin{tabular}{|l|}
12 \\
months
\end{tabular} & NR & $9(5.4 \%)$ & NR & NR & $\begin{array}{l}\text { AO: } \\
16(9.8 \%) \\
\text { NO: } 18 \\
(10.8 \%)\end{array}$ & $\mathrm{NR}$ & $\begin{array}{l}\mathrm{AO}: \mathrm{P}=0.13 \\
\mathrm{NI}: \mathrm{P}=0.16\end{array}$ \\
\hline \multirow[t]{3}{*}{$\begin{array}{l}\text { Markham, } \\
2012\end{array}$} & $\begin{array}{l}\text { Unprotected sex } \\
\text { at last vaginal } \\
\text { intercourse }\end{array}$ & \begin{tabular}{|l|}
26 \\
months
\end{tabular} & NR & NR & NR & NR & NR & $\mathrm{NR}$ & $\begin{array}{l}\text { AOR: } 0.67 \\
(\mathrm{P}<0.05 \\
95 \% \text { CI } 0.47- \\
0.96)\end{array}$ \\
\hline & $\begin{array}{l}\text { Number of } \\
\text { times having } \\
\text { vaginal sex in } \\
\text { the last } 3 \\
\text { months without } \\
\text { a condom: one } \\
\text { or more vs. zero }\end{array}$ & $\begin{array}{l}26 \\
\text { months }\end{array}$ & NR & NR & NR & NR & NR & NR & $\begin{array}{l}\text { AOR: } 0.59 \\
(\mathrm{P}<0.05 \\
95 \% \text { CI } 0.36- \\
0.95)\end{array}$ \\
\hline & $\begin{array}{l}\text { Number of } \\
\text { times having } \\
\text { anal sex in the } \\
\text { last } 3 \text { months } \\
\text { without a } \\
\text { condom: one or } \\
\text { more vs. zero }\end{array}$ & \begin{tabular}{|l|}
26 \\
months
\end{tabular} & NR & NR & NR & NR & NR & NR & $\begin{array}{l}\text { AOR: } 0.96 \\
(\mathrm{P}<0.05 \\
95 \% \text { CI } 0.45- \\
2.06)\end{array}$ \\
\hline \multirow[t]{3}{*}{$\begin{array}{l}\text { Morrison- } \\
\text { Beedy, } \\
2014\end{array}$} & $\begin{array}{l}\text { Any episodes of } \\
\text { unprotected } \\
\text { vaginal sex }\end{array}$ & $\begin{array}{l}12 \\
\text { months }\end{array}$ & $\begin{array}{l}216 \\
(66.7 \%)\end{array}$ & $\begin{array}{l}170 \\
(68.3 \%)\end{array}$ & NR & $\begin{array}{l}211 \\
(68.3 \%)\end{array}$ & $\begin{array}{l}171 \\
(72.8 \%)\end{array}$ & $\mathrm{NR}$ & $P>0.10$ \\
\hline & $\begin{array}{l}\text { Any episodes of } \\
\text { unprotected } \\
\text { vaginal sex with } \\
\text { steady partner }\end{array}$ & $\begin{array}{l}12 \\
\text { months }\end{array}$ & $\begin{array}{l}206 \\
(63.6 \%)\end{array}$ & $\begin{array}{l}154 \\
(63.4 \%)\end{array}$ & $\mathrm{NR}$ & $\begin{array}{l}190 \\
(61.5 \%)\end{array}$ & $\begin{array}{l}160 \\
(69.3 \%)\end{array}$ & NR & $P>0.10$ \\
\hline & $\begin{array}{l}\text { Any episodes of } \\
\text { unprotected } \\
\text { vaginal sex with } \\
\text { non-steady } \\
\text { partner(s) }\end{array}$ & $\begin{array}{l}12 \\
\text { months }\end{array}$ & $\begin{array}{l}41 \\
(12.8 \%)\end{array}$ & $\begin{array}{l}29 \\
(11.9 \%)\end{array}$ & NR & $\begin{array}{l}47 \\
(15.3 \%)\end{array}$ & $\begin{array}{l}36 \\
(15.3 \%)\end{array}$ & NR & $P>0.10$ \\
\hline Oman, 2018 & $\begin{array}{l}\text { Had sex without } \\
\text { using birth } \\
\text { control in past } 3 \\
\text { months }\end{array}$ & \begin{tabular}{|l|}
12 \\
months
\end{tabular} & $\begin{array}{l}131 \\
(27.2 \%)\end{array}$ & $\begin{array}{l}158 \\
(37.9 \%)\end{array}$ & NR & $\begin{array}{l}133 \\
(26.8 \%)\end{array}$ & $\begin{array}{l}165 \\
(38.0 \%)\end{array}$ & NR & $\begin{array}{l}\text { AOR: } 0.92 \\
(95 \% \text { CI } 0.67- \\
1.25)\end{array}$ \\
\hline \multirow[t]{2}{*}{$\begin{array}{l}\text { Sieving, } \\
2011\end{array}$} & $\begin{array}{l}\text { Condom use } \\
\text { consistency }\end{array}$ & \begin{tabular}{|l|}
12 \\
months
\end{tabular} & $\begin{array}{l}\text { Never: } 14 \% \\
\leq \square \text { time: } 32 \% \\
>\square \text { time: } 23 \% \\
\text { Every time: } 31 \%\end{array}$ & Mean score: 0.96 & NR & $\begin{array}{l}\text { Never }: 9 \% \\
\leq 0 \text { time: } \\
33 \% \\
>0 \text { time: } \\
26 \% \\
\text { Every } \\
\text { time: } 32 \%\end{array}$ & $\begin{array}{l}\text { Mean } \\
\text { score: } \\
0.66\end{array}$ & NR & $\begin{array}{l}\text { AOR: } 1.45 \\
(\mathrm{P}=0,95 \% \mathrm{CI} \\
1.26-1.67)\end{array}$ \\
\hline & $\begin{array}{l}\text { Hormonal use } \\
\text { consistency }\end{array}$ & \begin{tabular}{|l|}
12 \\
months
\end{tabular} & $\begin{array}{l}\text { No use: } 36 \% \\
1 \text { month: } 21 \%\end{array}$ & Mean score: 4.27 & NR & $\begin{array}{l}\text { No use: } \\
45 \%\end{array}$ & $\begin{array}{l}\text { Mean } \\
\text { score: } \\
2.91\end{array}$ & NR & $\begin{array}{l}\text { AOR: } 1.46 \\
(\mathrm{P}=0,95 \% \mathrm{CI} \\
1.13-1.89)\end{array}$ \\
\hline
\end{tabular}

Page 16/26 


\begin{tabular}{|c|c|c|c|c|c|c|c|c|c|}
\hline & & & $\begin{array}{l}2 \text { months: } 12 \% \\
3 \text { months: } 5 \% \\
4 \text { months: } 9 \% \\
5 \text { months: } 1 \% \\
6 \text { months: } 6 \% \\
7 \text { months: } 10 \%\end{array}$ & & & $\begin{array}{l}1 \text { month: } \\
7 \% \\
2 \text { months: } \\
14 \% \\
3 \text { months: } \\
8 \% \\
4 \text { months: } \\
3 \% \\
5 \text { months: } \\
6 \% \\
6 \text { months: } \\
9 \% \\
7 \text { months: } \\
8 \%\end{array}$ & & & \\
\hline & $\begin{array}{l}\text { Dual method } \\
\text { use consistency }\end{array}$ & $\begin{array}{l}12 \\
\text { months }\end{array}$ & NR & Mean score: 0.83 & NR & NR & $\begin{array}{l}\text { Mean } \\
\text { score: } \\
0.53\end{array}$ & NR & $\begin{array}{l}\text { AOR: } 1.58 \\
(\mathrm{P}=0.01 \\
95 \% \mathrm{CI} 1.03- \\
2.42)\end{array}$ \\
\hline \multirow[t]{5}{*}{$\begin{array}{l}\text { Tortolero, } \\
2014\end{array}$} & $\begin{array}{l}\text { Condom at last } \\
\text { sex (for vaginal } \\
\text { sex only) }\end{array}$ & $\begin{array}{l}\text { Ninth } \\
\text { grade } \\
\text { follow- } \\
\text { up }\end{array}$ & $26(7.4 \%)$ & NR & NR & $32(5.7)$ & NR & NR & $\begin{array}{l}\text { ARR: } 1.04 \\
(95 \% \text { CI } 0.87- \\
1.25)\end{array}$ \\
\hline & $\begin{array}{l}\text { Number of } \\
\text { times having } \\
\text { vaginal sex in } \\
\text { the last } 3 \\
\text { months without } \\
\text { a condom: } 1 \text { or } \\
\text { more versos } 0\end{array}$ & $\begin{array}{l}\text { Ninth } \\
\text { grade } \\
\text { follow- } \\
\text { up }\end{array}$ & NR & NR & NR & NR & NR & NR & $\begin{array}{l}\text { ARR: } 0.92 \\
\text { (95\%CI } 0.71- \\
1.19)\end{array}$ \\
\hline & $\begin{array}{l}\text { Number of } \\
\text { times having } \\
\text { anal sex in the } \\
\text { last } 3 \text { months } \\
\text { without a } \\
\text { condom: } 1 \text { or } \\
\text { more versos } 0\end{array}$ & $\begin{array}{l}\text { Ninth } \\
\text { grade } \\
\text { follow- } \\
\text { up }\end{array}$ & NR & NR & NR & NR & NR & NR & $\begin{array}{l}\text { ARR: } 1.12 \\
(95 \% \text { CI } 0.38- \\
3.35)\end{array}$ \\
\hline & $\begin{array}{l}\text { Number of } \\
\text { vaginal sex } \\
\text { partners in the } \\
\text { last } 3 \text { months } \\
\text { without a } \\
\text { condom: } 1 \text { or } \\
\text { more versus } 0\end{array}$ & $\begin{array}{l}\text { Ninth } \\
\text { grade } \\
\text { follow- } \\
\text { up }\end{array}$ & NR & NR & NR & NR & NR & NR & $\begin{array}{l}\text { ARR: } 0.86 \\
\text { (95\%CI 0.63- } \\
1.18)\end{array}$ \\
\hline & $\begin{array}{l}\text { Number of } \\
\text { times having sex } \\
\text { in the last } 3 \\
\text { months without } \\
\text { effective } \\
\text { pregnancy } \\
\text { prevention }\end{array}$ & $\begin{array}{l}\text { Ninth } \\
\text { grade } \\
\text { follow- } \\
\text { up }\end{array}$ & NR & NR & NR & NR & NR & NR & $\begin{array}{l}\text { ARR: } 0.59 \\
(95 \% \text { CI } 0.51- \\
1.35)\end{array}$ \\
\hline $\begin{array}{l}\text { LaChausse, } \\
2016\end{array}$ & $\begin{array}{l}\text { Ever had sexual } \\
\text { intercourse } \\
\text { without using } \\
\text { birth control in } \\
\text { the past } 3 \\
\text { months }\end{array}$ & $\begin{array}{l}6 \\
\text { months }\end{array}$ & $2 \%$ & $\begin{array}{l}0.04 \\
(0.18)\end{array}$ & NR & $3 \%$ & $\begin{array}{l}0.06 \\
(0.23)\end{array}$ & NR & $\begin{array}{l}\text { Mean } \\
\text { difference: } \\
-0.02(\mathrm{P}=0.01)\end{array}$ \\
\hline $\begin{array}{l}\text { Kaufman, } \\
2014\end{array}$ & $\begin{array}{l}\text { Condom use at } \\
\text { last sex }\end{array}$ & $\begin{array}{l}12 \\
\text { months }\end{array}$ & $80.65 \%$ & NR & NR & $76.19 \%$ & NR & NR & $\begin{array}{l}\text { Girls: B: } \\
-0.498 \\
(\mathrm{P}=0.736, \\
95 \% \mathrm{CI}-3.391- \\
2.394) \\
\\
\text { Boys: B: }-0.704 \\
(\mathrm{P}=0.464, \\
95 \% \mathrm{CI}-2.589- \\
1.181)\end{array}$ \\
\hline $\begin{array}{l}\text { Aarons, } \\
2000\end{array}$ & $\begin{array}{l}\text { Used birth } \\
\text { control/condoms }\end{array}$ & $\begin{array}{l}12 \\
\text { months }\end{array}$ & $\begin{array}{l}\text { Females: } 39.1 \% \\
\text { (of 139) }\end{array}$ & NR & NR & $\begin{array}{l}\text { Females: } \\
27.3 \% \text { (of }\end{array}$ & NR & NR & $\begin{array}{l}\text { Females: AOR: } \\
3.39(\mathrm{P}<0.05\end{array}$ \\
\hline
\end{tabular}




\begin{tabular}{|c|c|c|c|}
\hline turental & 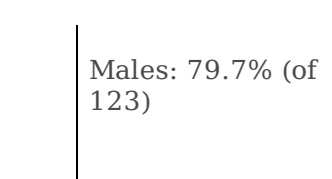 & $\mid \begin{array}{lll}\text { and } \\
\text { and }\end{array}$ & 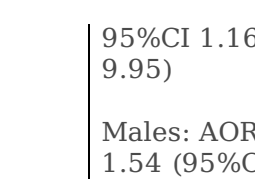 \\
\hline 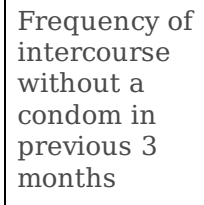 & & & 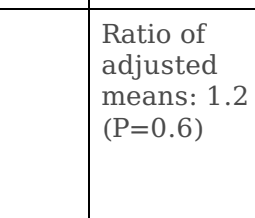 \\
\hline 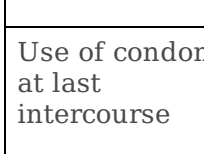 & 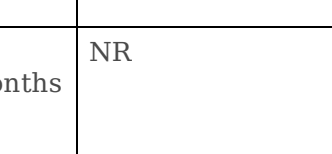 & & 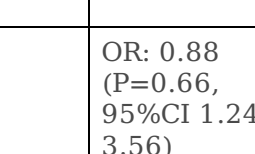 \\
\hline 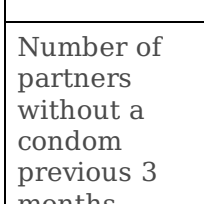 & nats & & 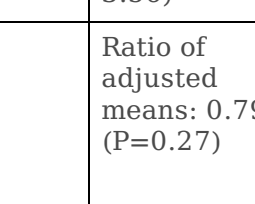 \\
\hline 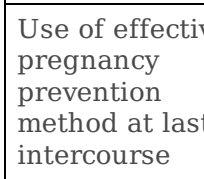 & nats & & 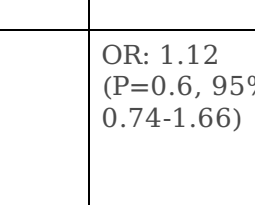 \\
\hline 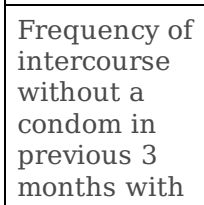 & nats & & \\
\hline 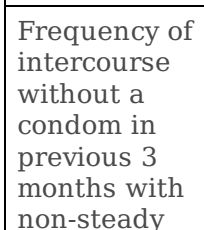 & natis & & 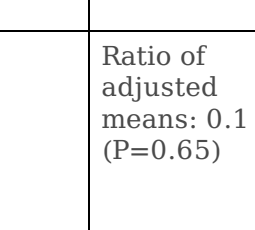 \\
\hline 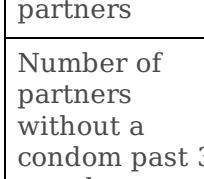 & $=$ & & 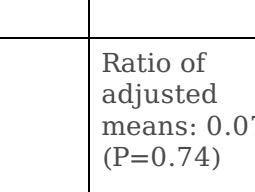 \\
\hline 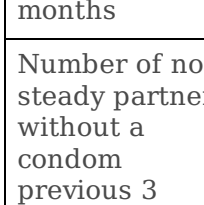 & antal" & & 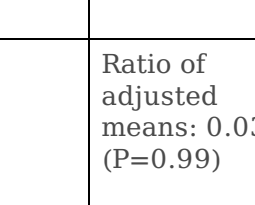 \\
\hline 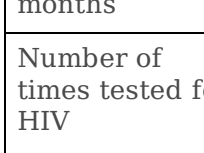 & natis $=$ N" & & 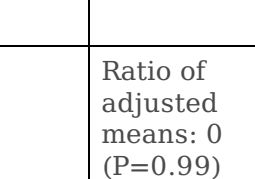 \\
\hline 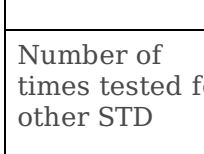 & 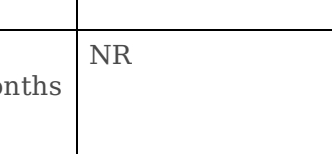 & & \\
\hline 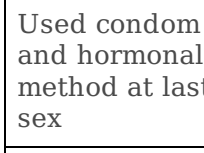 & "nes $m$ & & \\
\hline & 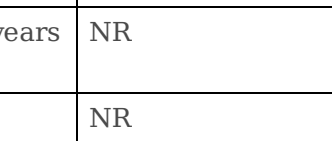 & & $\sqrt{2}$ \\
\hline
\end{tabular}

Page 18/26 


\begin{tabular}{|c|c|c|c|c|c|c|c|c|c|}
\hline \multirow[t]{2}{*}{1992} & of condom use & months & & (SD): 4.25(22) & & & \begin{tabular}{|l} 
(SD): \\
$3.50(21)$
\end{tabular} & & \begin{tabular}{|l} 
difference: \\
0.85 (95\%CI \\
$0.14-1.56)$
\end{tabular} \\
\hline & $\begin{array}{l}\text { Number of days } \\
\text { the respondent } \\
\text { did not use a } \\
\text { condom during } \\
\text { coitus }\end{array}$ & $\begin{array}{l}3 \\
\text { months }\end{array}$ & NR & $\begin{array}{l}\text { Mean } \\
\text { (SD): 0.64(58) }\end{array}$ & NR & NR & $\begin{array}{l}\text { Mean } \\
\text { (SD): } \\
2.38(48)\end{array}$ & NR & \begin{tabular}{|l} 
Mean \\
difference: \\
$-1.73(95 \%$ CI \\
$-2.86--0.60)$
\end{tabular} \\
\hline \multirow[t]{2}{*}{ Klein, 2011} & $\begin{array}{l}\text { Number of } \\
\text { vaginal sex acts } \\
\text { with condom } \\
\text { last } 90 \text { days }\end{array}$ & $\begin{array}{l}3 \\
\text { months }\end{array}$ & 2.67 & 5.53 & \begin{tabular}{|l|}
2.86 \\
$(\mathrm{P}=0.05$ \\
$95 \% \mathrm{CI}$ \\
$0.02-$ \\
$5.71)$
\end{tabular} & 4.79 & 4.67 & $\begin{array}{l}-0.13 \\
(P=0.95 \\
95 \% \mathrm{CI} \\
-4.02- \\
3.76)\end{array}$ & NR \\
\hline & $\begin{array}{l}\text { Proportion of } \\
\text { vaginal sex acts } \\
\text { with condoms } \\
\text { last } 90 \text { days } \\
\text { (sexually } \\
\text { initiatied who } \\
\text { have had } \\
\text { vaginal sex in } \\
\text { the last } 90 \text { days } \\
\text { only) }\end{array}$ & $\begin{array}{l}3 \\
\text { months }\end{array}$ & 0.51 & 0.71 & \begin{tabular}{|l|}
0.2 \\
$(\mathrm{P}=0.05$ \\
$95 \% \mathrm{CI}$ \\
$0.00-$ \\
$0.40)$
\end{tabular} & 0.72 & 0.57 & $\begin{array}{l}-0.16 \\
(P=0.12 \\
95 \% \mathrm{CI} \\
-0.36- \\
0.05)\end{array}$ & NR \\
\hline \multirow[t]{3}{*}{$\begin{array}{l}\text { Walter, } \\
1993\end{array}$} & $\begin{array}{l}\text { Percentage of } \\
\text { students who } \\
\text { changed for } \\
\text { high-risk } \\
\text { partners }\end{array}$ & $\begin{array}{l}3 \\
\text { months }\end{array}$ & NR & NR & NR & NR & NR & NR & $\mathrm{P}<0.05$ \\
\hline & $\begin{array}{l}\text { Percentage of } \\
\text { students who } \\
\text { changed for } \\
\text { monogamy }\end{array}$ & $\begin{array}{l}3 \\
\text { months }\end{array}$ & NR & NR & NR & NR & NR & NR & $\mathrm{P}<0.05$ \\
\hline & $\begin{array}{l}\text { Percentage } \\
\text { change of } \\
\text { students with } \\
\text { consistent } \\
\text { condom use }\end{array}$ & $\begin{array}{l}3 \\
\text { months }\end{array}$ & NR & NR & NR & NR & NR & NR & $\mathrm{P}<0.05$ \\
\hline \multirow[t]{5}{*}{$\begin{array}{l}\text { Scholes, } \\
2003\end{array}$} & $\begin{array}{l}\text { Any use of } \\
\text { condoms in } \\
\text { prior } 3 \text { months } \\
\text { with: any } \\
\text { partner }\end{array}$ & $\begin{array}{l}6 \\
\text { months }\end{array}$ & $71 \%$ & $72.8 \%$ & NR & $73 \%$ & $63.00 \%$ & NR & $\begin{array}{l}\text { OR: } 1.86 \\
(\mathrm{P}=0.0005 \\
95 \% \mathrm{CI} 1.32- \\
2.65)\end{array}$ \\
\hline & $\begin{array}{l}\text { Any use of } \\
\text { condoms in } \\
\text { prior } 3 \text { months } \\
\text { with: a primary } \\
\text { partner }\end{array}$ & $\begin{array}{l}6 \\
\text { months }\end{array}$ & $67 \%$ & $69.10 \%$ & NR & $68 \%$ & $57.90 \%$ & NR & $\begin{array}{l}\text { OR: } 1.97 \\
(\mathrm{P}=0.003 \\
95 \% \mathrm{CI} 1.37- \\
2.86)\end{array}$ \\
\hline & $\begin{array}{l}\text { Any use of } \\
\text { condoms in } \\
\text { prior } 3 \text { months } \\
\text { with: a non- } \\
\text { primary partner }\end{array}$ & $\begin{array}{l}6 \\
\text { months }\end{array}$ & $79 \%$ & $87.50 \%$ & NR & $73 \%$ & $76.90 \%$ & NR & $\begin{array}{l}\text { OR: } 2.25 \\
(\mathrm{P}=0.09 \\
95 \% \text { CI } 0.91- \\
6.07)\end{array}$ \\
\hline & $\begin{array}{l}\text { Average } \\
\text { percentage of } \\
\text { time condoms } \\
\text { used with any } \\
\text { partner }\end{array}$ & $\begin{array}{l}6 \\
\text { months }\end{array}$ & NR & $52.70 \%$ & NR & NR & $47.90 \%$ & NR & $\begin{array}{l}\text { OR: } 5.2 \\
(\mathrm{P}=0.05 \\
95 \% \text { CI 0.4- } \\
10.4)\end{array}$ \\
\hline & $\begin{array}{l}\text { Consistent use } \\
\text { of condoms in } \\
\text { prior } 3 \text { months } \\
\text { with all partners }\end{array}$ & $\begin{array}{l}6 \\
\text { months }\end{array}$ & NR & $36.80 \%$ & NR & NR & $33.50 \%$ & NR & $\begin{array}{l}\text { OR: } 1.24 \\
(\mathrm{P}=0.21 \\
95 \% \mathrm{CI} 0.89- \\
1.73)\end{array}$ \\
\hline \multirow[t]{2}{*}{$\begin{array}{l}\text { Jemmott, } \\
2010\end{array}$} & $\begin{array}{l}\text { Consistently use } \\
\text { condoms in } \\
\text { prior } 90 \text { days }\end{array}$ & $\begin{array}{l}12 \\
\text { months }\end{array}$ & $\begin{array}{l}210 \\
(56.9 \%)\end{array}$ & $\begin{array}{l}156 \\
(56.1 \%)\end{array}$ & NR & $\begin{array}{l}205 \\
(60.3 \%)\end{array}$ & $\begin{array}{l}126 \\
(50.0 \%)\end{array}$ & NR & $\begin{array}{l}\text { OR: } 1.39 \\
(\mathrm{P}=0.02 \\
95 \% \mathrm{CI} 1.06- \\
1.84)\end{array}$ \\
\hline & $\begin{array}{l}\text { Proportion of } \\
\text { condom- } \\
\text { protected sexual } \\
\text { intercourse in } \\
\text { prior } 90 \text { days }\end{array}$ & $\begin{array}{l}12 \\
\text { months }\end{array}$ & $\begin{array}{l}\text { Mean } \\
(\mathrm{SE}): \\
0.72 \\
(0.02)\end{array}$ & $\begin{array}{l}\text { Mean } \\
(\mathrm{SE}): \\
0.72 \\
(0.02)\end{array}$ & NR & $\begin{array}{l}\text { Mean } \\
(\mathrm{SE}): \\
0.76 \\
(0.02)\end{array}$ & $\begin{array}{l}\text { Mean } \\
(\mathrm{SE}): \\
0.69 \\
(0.03)\end{array}$ & NR & $\begin{array}{l}\text { Beta: } 0.06 \\
(\mathrm{P}=0.04,0.00- \\
0.12)\end{array}$ \\
\hline
\end{tabular}




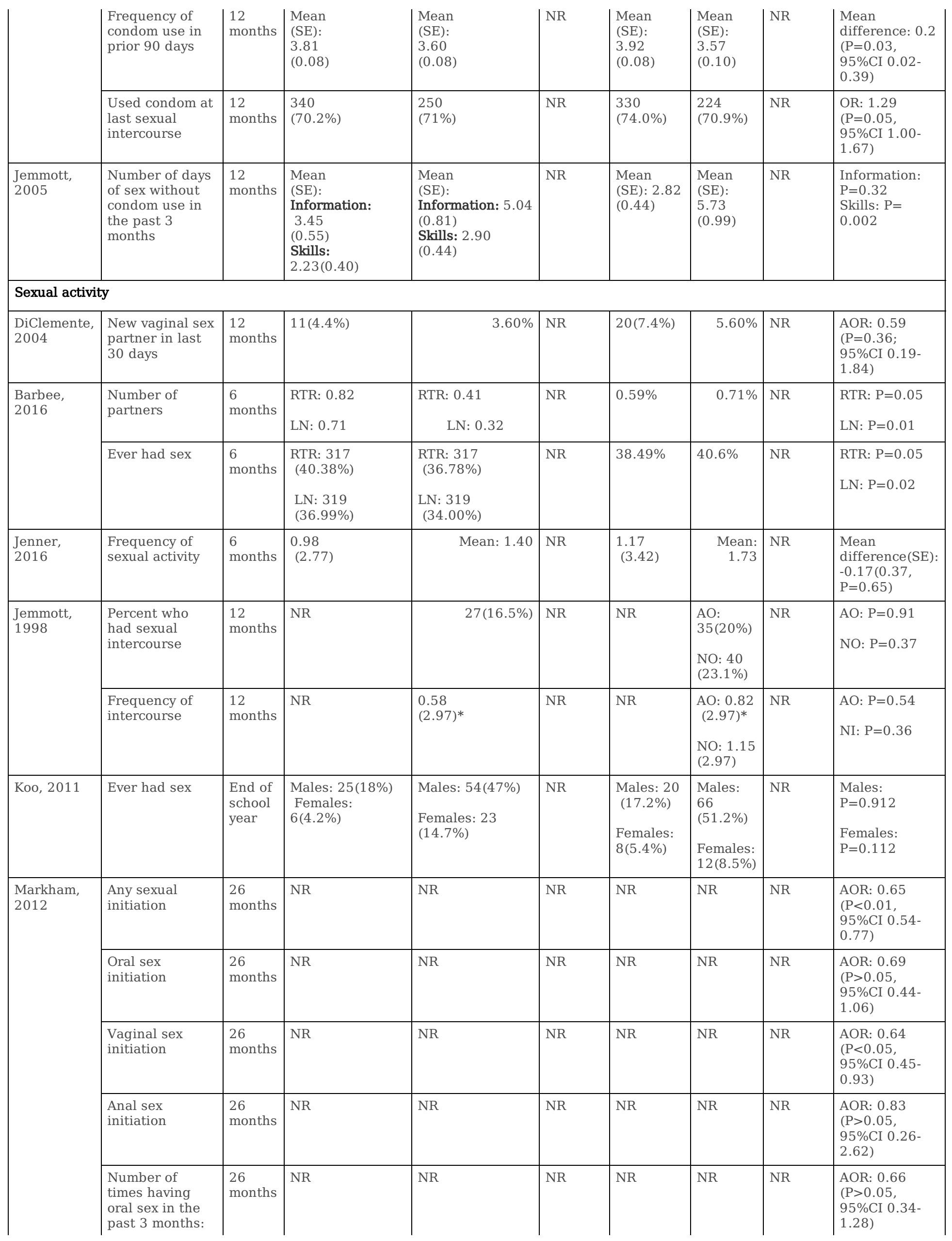




\begin{tabular}{|c|c|c|c|c|c|c|c|c|c|}
\hline \multicolumn{10}{|c|}{\begin{tabular}{l|l}
2 or more vs. 1 \\
or none
\end{tabular}} \\
\hline & $\begin{array}{l}\text { Number of } \\
\text { times having } \\
\text { vaginal sex in } \\
\text { the past } 3 \\
\text { months: } 2 \text { or } \\
\text { more vs. } 1 \text { or } \\
\text { none }\end{array}$ & $\begin{array}{l}26 \\
\text { months }\end{array}$ & NR & NR & NR & NR & NR & NR & $\begin{array}{l}\text { AOR: } 0.73 \\
(\mathrm{P}<0.05, \\
95 \% \text { CI } 0.53- \\
1.00)\end{array}$ \\
\hline & $\begin{array}{l}\text { Number of } \\
\text { times having } \\
\text { anal sex in the } \\
\text { past } 3 \text { months: } \\
2 \text { or more vs. } 1 \\
\text { or none }\end{array}$ & $\begin{array}{l}26 \\
\text { months }\end{array}$ & NR & NR & NR & NR & NR & NR & $\begin{array}{l}\text { AOR: } 0.53 \\
(\mathrm{P}<0.01 \\
95 \% \text { CI } 0.33- \\
0.84)\end{array}$ \\
\hline & $\begin{array}{l}\text { \# of vaginal sex } \\
\text { partners in past } \\
3 \text { months }(2+\text { vs } \\
\text { one or none) }\end{array}$ & $\begin{array}{l}26 \\
\text { months }\end{array}$ & NR & NR & NR & NR & NR & NR & $\begin{array}{l}1.15(\mathrm{P}>0.05 \\
95 \% \mathrm{CI} 0.60- \\
2.22)\end{array}$ \\
\hline & $\begin{array}{l}\text { \# of anal sex } \\
\text { partners in past } \\
3 \text { months }(2+\text { vs } \\
\text { one or none) }\end{array}$ & $\begin{array}{l}26 \\
\text { months }\end{array}$ & NR & NR & NR & NR & NR & NR & $\begin{array}{l}\text { NR** } \\
\text { (Sample size } \\
\text { too small) }\end{array}$ \\
\hline \multirow{4}{*}{$\begin{array}{l}\text { Morrison- } \\
\text { Beedy, } \\
2013\end{array}$} & $\begin{array}{l}\text { Any episodes of } \\
\text { vaginal sex }\end{array}$ & $\begin{array}{l}12 \\
\text { months }\end{array}$ & $\begin{array}{l}292 \\
(90.1 \%)\end{array}$ & $\begin{array}{l}206 \\
(82.7 \%)\end{array}$ & NR & $\begin{array}{l}283 \\
(91.6 \%)\end{array}$ & $\begin{array}{l}198 \\
(84.3 \%)\end{array}$ & NR & $P>0.10$ \\
\hline & $\begin{array}{l}\text { Number of girls } \\
\text { with } 0 \text { sexual } \\
\text { partners }\end{array}$ & $\begin{array}{l}12 \\
\text { months }\end{array}$ & $25(7.7 \%)$ & $31(12.4 \%)$ & NR & $14(4.5 \%)$ & $23(9.7 \%)$ & NR & NR \\
\hline & $\begin{array}{l}\text { Number of girls } \\
\text { with } 1 \text { sexual } \\
\text { partner }\end{array}$ & $\begin{array}{l}12 \\
\text { months }\end{array}$ & $\begin{array}{l}207 \\
(63.7 \%)\end{array}$ & \begin{tabular}{|l}
173 \\
$(69.5 \%)$
\end{tabular} & NR & $\begin{array}{l}197 \\
(63.8 \%)\end{array}$ & $\begin{array}{l}164 \\
(69.5 \%)\end{array}$ & NR & $\begin{array}{l}\text { OR: } 0.785 \\
(P>0.05 \\
95 \% \text { CI } 0.434- \\
1.421)\end{array}$ \\
\hline & $\begin{array}{l}\text { Number of girls } \\
\text { with } 2 \text { or more } \\
\text { sexual partners }\end{array}$ & $\begin{array}{l}12 \\
\text { months }\end{array}$ & $\begin{array}{l}93 \\
(28.6 \%)\end{array}$ & $\begin{array}{l}45 \\
(18.1 \%)\end{array}$ & $\mathrm{NR}$ & $\begin{array}{l}98 \\
(31.7 \%)\end{array}$ & $\begin{array}{l}49 \\
(20.8 \%)\end{array}$ & NR & $\begin{array}{l}\text { OR: } 0.715 \\
(\mathrm{P}>0.06 \\
95 \% \text { CI } 0.359- \\
1.424)\end{array}$ \\
\hline \multirow[t]{2}{*}{$\begin{array}{l}\text { O'Donnell, } \\
2017\end{array}$} & $\begin{array}{l}\text { Touched/been } \\
\text { touched }\end{array}$ & $\begin{array}{l}12 \\
\text { months }\end{array}$ & NR & NR & NR & NR & NR & NR & $\begin{array}{l}\text { AOR: } 0.69 \\
(\mathrm{P}<0.001 \\
95 \% \text { CI } 0.56- \\
0.84)\end{array}$ \\
\hline & Sex initiation & $\begin{array}{l}12 \\
\text { months }\end{array}$ & NR & NR & NR & NR & NR & NR & $\begin{array}{l}\text { AOR: } 0.74 \\
(\mathrm{P}<0.01 \\
95 \% \text { CI } 0.61- \\
0.90)\end{array}$ \\
\hline \multirow[t]{4}{*}{$\begin{array}{l}\text { Peskin, } \\
2015\end{array}$} & $\begin{array}{l}\text { Ever had sex } \\
\text { (any) }\end{array}$ & $\begin{array}{l}12 \\
\text { months }\end{array}$ & $\begin{array}{l}153 \\
(19.9 \%)\end{array}$ & NR & NR & $\begin{array}{l}114 \\
(18.8 \%)\end{array}$ & NR & NR & $\begin{array}{l}\text { AOR: } 1(95 \% \mathrm{CI} \\
0.70-1.41)\end{array}$ \\
\hline & Oral sex & $\begin{array}{l}12 \\
\text { months }\end{array}$ & $102(13.3 \%)$ & NR & NR & $61(10.1 \%)$ & NR & NR & $\begin{array}{l}\text { AOR: } 1.09 \\
(95 \% \text { CI } 0.67- \\
1.76)\end{array}$ \\
\hline & Vaginal sex & $\begin{array}{l}12 \\
\text { months }\end{array}$ & $117(15.2 \%)$ & NR & NR & $85(14 \%)$ & NR & NR & $\begin{array}{l}\text { AOR: } 1.01 \\
(95 \% \text { CI } 0.69- \\
1.48)\end{array}$ \\
\hline & Anal sex & $\begin{array}{l}12 \\
\text { months }\end{array}$ & $48(6.3 \%)$ & NR & NR & $29(4.8 \%)$ & NR & NR & $\begin{array}{l}\text { AOR: } 1.05 \\
(95 \% \text { CI } 0.47- \\
2.35)\end{array}$ \\
\hline $\begin{array}{l}\text { Sieving, } \\
2011\end{array}$ & $\begin{array}{l}\text { Number of male } \\
\text { sex partners, } \\
\text { past } 6 \text { months }\end{array}$ & $\begin{array}{l}12 \\
\text { months }\end{array}$ & $\begin{array}{l}1.54 \\
(0.21)\end{array}$ & Mean score: 1.55 & NR & $\begin{array}{l}1.76 \\
(0.07)\end{array}$ & $\begin{array}{l}\text { Mean } \\
\text { score: } \\
1.44\end{array}$ & NR & $\begin{array}{l}\text { AOR: } 1.08 \\
(\mathrm{P}=0.44 \\
95 \% \text { CI } 0.89- \\
1.31)\end{array}$ \\
\hline $\begin{array}{l}\text { Tortolero, } \\
2010\end{array}$ & $\begin{array}{l}\text { Initiatied sex } \\
\text { (among those } \\
\text { who reported no } \\
\text { experience at } \\
\text { seventh-grade } \\
\text { baseline but } \\
\text { reporting } \\
\text { having initiatied }\end{array}$ & $\begin{array}{l}\text { Ninth } \\
\text { grade } \\
\text { follow- } \\
\text { up }\end{array}$ & 0 & $\begin{array}{l}308 \\
(23.4 \%)\end{array}$ & NR & 0 & $\begin{array}{l}509 \\
(29.9 \%)\end{array}$ & NR & $\begin{array}{l}\text { ARR: } 1.29 \\
(\mathrm{P} \leq 0.05 \\
95 \% \text { CI } 1.02- \\
1.64)\end{array}$ \\
\hline
\end{tabular}




\begin{tabular}{|c|c|c|c|c|c|c|c|c|}
\hline $\begin{array}{l}\text { at ninth-grade } \\
\text { follow-up) }\end{array}$ & & & & & & & & \\
\hline $\begin{array}{l}\text { Initiatied oral } \\
\text { sex (among } \\
\text { those who } \\
\text { reported no } \\
\text { experience at } \\
\text { seventh-grade } \\
\text { baseline but } \\
\text { reporting } \\
\text { having initiatied } \\
\text { at ninth-grade } \\
\text { follow-up) }\end{array}$ & $\begin{array}{l}\text { Ninth } \\
\text { grade } \\
\text { follow- } \\
\text { up }\end{array}$ & 0 & $\begin{array}{l}319 \\
\\
\end{array}$ & NR & 0 & $\begin{array}{l}512 \\
(17.6 \%)\end{array}$ & NR & $\begin{array}{l}\text { ARR: } 1.76 \\
(\mathrm{P} \leq 0.01 \\
95 \% \text { CI } 1.21- \\
2.56)\end{array}$ \\
\hline $\begin{array}{l}\text { Initiatied } \\
\text { vaginal sex } \\
\text { (among those } \\
\text { who reported no } \\
\text { experience at } \\
\text { seventh-grade } \\
\text { baseline but } \\
\text { reporting } \\
\text { having initiatied } \\
\text { at ninth-grade } \\
\text { follow-up) }\end{array}$ & $\begin{array}{l}\text { Ninth } \\
\text { grade } \\
\text { follow- } \\
\text { up }\end{array}$ & 0 & 305 (22.3\%) & NR & 0 & $\begin{array}{l}499 \\
(26.9 \%)\end{array}$ & NR & $\begin{array}{l}\text { ARR: } 1.26 \\
(95 \% \text { CI 0.98- } \\
1.61)\end{array}$ \\
\hline $\begin{array}{l}\text { Initiatied anal } \\
\text { sex (among } \\
\text { those who } \\
\text { reported no } \\
\text { experience at } \\
\text { seventh-grade } \\
\text { baseline but } \\
\text { reporting } \\
\text { having initiatied } \\
\text { at ninth-grade } \\
\text { follow-up) }\end{array}$ & $\begin{array}{l}\text { Ninth } \\
\text { grade } \\
\text { follow- } \\
\text { up }\end{array}$ & 0 & $\begin{array}{l}321 \\
(3.7 \%)\end{array}$ & NR & 0 & $\begin{array}{l}514 \\
(9.9 \%)\end{array}$ & NR & $\begin{array}{l}\text { ARR: } 2.67 \\
(\mathrm{P} \leq 0.01 \\
95 \% \text { CI } 1.45- \\
4.94)\end{array}$ \\
\hline $\begin{array}{l}\text { Number of } \\
\text { times having } \\
\text { oral sex in the } \\
\text { last } 3 \text { months: } 2 \\
\text { or more versus } \\
1\end{array}$ & $\begin{array}{l}\text { Ninth } \\
\text { grade } \\
\text { follow- } \\
\text { up }\end{array}$ & NR & NR & NR & NR & NR & NR & $\begin{array}{l}\text { ARR: } 0.93 \\
(95 \% \text { CI } 0.69- \\
1.28)\end{array}$ \\
\hline $\begin{array}{l}\text { Number of } \\
\text { times having } \\
\text { vaginal sex in } \\
\text { the last } 3 \\
\text { months: } 2 \text { or } \\
\text { more versus } 1\end{array}$ & $\begin{array}{l}\text { Ninth } \\
\text { grade } \\
\text { follow- } \\
\text { up }\end{array}$ & NR & NR & NR & NR & NR & NR & $\begin{array}{l}\text { ARR: } 1.3 \\
(\mathrm{P}<0.05, \\
95 \% \text { CI } 1.02- \\
1.66)\end{array}$ \\
\hline $\begin{array}{l}\text { Number of } \\
\text { times having } \\
\text { anal sex in the } \\
\text { last } 3 \text { months: } 2 \\
\text { or more versus } \\
1\end{array}$ & $\begin{array}{l}\text { Ninth } \\
\text { grade } \\
\text { follow- } \\
\text { up }\end{array}$ & NR & NR & NR & NR & NR & NR & $\begin{array}{l}\text { ARR: } 27.14 \\
\text { (95\%CI } 0.10- \\
7693\end{array}$ \\
\hline $\begin{array}{l}\text { Number of } \\
\text { lifetime oral sex } \\
\text { partners ( } 2 \text { or } \\
\text { more versus } 1 \text { ) }\end{array}$ & $\begin{array}{l}\text { Ninth } \\
\text { grade } \\
\text { follow- } \\
\text { up }\end{array}$ & NR & NR & NR & NR & NR & NR & $\begin{array}{l}\text { ARR: } 1.17 \\
(95 \% \text { CI } 0.82- \\
1.68)\end{array}$ \\
\hline $\begin{array}{l}\text { Number of } \\
\text { lifetime vaginal } \\
\text { sex partners ( } 2 \\
\text { or more versus } \\
1 \text { ) }\end{array}$ & $\begin{array}{l}\text { Ninth } \\
\text { grade } \\
\text { follow- } \\
\text { up }\end{array}$ & NR & NR & NR & NR & NR & NR & $\begin{array}{l}\text { ARR: } 1.05 \\
\text { (95\%CI 0.89- } \\
1.24)\end{array}$ \\
\hline $\begin{array}{l}\text { Number of } \\
\text { lifetime anal sex } \\
\text { partners ( } 2 \text { or } \\
\text { more versus } 1 \text { ) }\end{array}$ & $\begin{array}{l}\text { Ninth } \\
\text { grade } \\
\text { follow- } \\
\text { up }\end{array}$ & NR & NR & NR & NR & NR & NR & $\begin{array}{l}\text { ARR: } 0.89 \\
(95 \% \text { CI } 0.15- \\
4.81)\end{array}$ \\
\hline $\begin{array}{l}\text { Number of } \\
\text { vaginal sex } \\
\text { partners in the } \\
\text { last } 3 \text { months: } 2 \\
\text { or more versus } \\
1\end{array}$ & $\begin{array}{l}\text { Ninth } \\
\text { grade } \\
\text { follow- } \\
\text { up }\end{array}$ & $\mathrm{NR}$ & NR & NR & NR & NR & NR & $\begin{array}{l}\text { ARR: } 1.31 \\
\text { (95\%CI 0.83- } \\
2.07)\end{array}$ \\
\hline
\end{tabular}




\begin{tabular}{|c|c|c|c|c|c|c|c|c|c|}
\hline & $\begin{array}{l}\text { Number of anal } \\
\text { sex partners in } \\
\text { the last } 3 \\
\text { months: } 2 \text { or } \\
\text { more versus } 1\end{array}$ & $\begin{array}{l}\text { Ninth } \\
\text { grade } \\
\text { follow- } \\
\text { up }\end{array}$ & NR & NR & $\mathrm{NR}$ & NR & NR & NR & $\begin{array}{l}\text { NR } \\
\text { Unable to } \\
\text { estimate }\end{array}$ \\
\hline $\begin{array}{l}\text { LaChausse, } \\
2016\end{array}$ & $\begin{array}{l}\text { Ever had sexual } \\
\text { intercourse }\end{array}$ & $\begin{array}{l}6 \\
\text { months }\end{array}$ & $12 \%$ & $\begin{array}{l}0.14 \\
(0.34)\end{array}$ & $\mathrm{NR}$ & $12 \%$ & $\begin{array}{l}0.18 \\
(0.38)\end{array}$ & NR & $\begin{array}{l}\text { Mean } \\
\text { difference: } \\
-0.04(P=0.01)\end{array}$ \\
\hline \multirow[t]{2}{*}{$\begin{array}{l}\text { Kaufman, } \\
2014\end{array}$} & Ever had sex & $\begin{array}{l}12 \\
\text { months }\end{array}$ & $12.80 \%$ & NR & NR & $17.67 \%$ & NR & NR & $\begin{array}{l}\text { Girls: B: } \\
-0.516 \\
(\mathrm{P}=0.367, \\
95 \% \mathrm{CI}-1.638- \\
0.606) \\
\text { Boys: B: } 0.413 \\
(\mathrm{P}=0.321 \\
95 \% \mathrm{CI}-0.402- \\
1.229)\end{array}$ \\
\hline & $\begin{array}{l}\text { Had sex in last } \\
12 \text { months }\end{array}$ & $\begin{array}{l}12 \\
\text { months }\end{array}$ & $7.72 \%$ & NR & $\mathrm{NR}$ & $10.29 \%$ & NR & NR & $\begin{array}{l}\text { B: } \\
\text { Girls: B: } \\
0.135 \\
(\mathrm{P}=0.864, \\
95 \% \mathrm{CI}-1.409- \\
1.679) \\
\\
\text { Boys: B: } 0.664 \\
(\mathrm{P}=0.223 \\
95 \% \mathrm{CI}-0.405- \\
1.733)\end{array}$ \\
\hline $\begin{array}{l}\text { Aarons, } \\
2000\end{array}$ & Virginity rates & $\begin{array}{l}12 \\
\text { months }\end{array}$ & $\begin{array}{l}\text { Females: } 83.7 \% \\
\text { (of 139) } \\
\text { Males: } 44.9 \% \text { (of } \\
123 \text { ) }\end{array}$ & NR & NR & $\begin{array}{l}\text { Females: } \\
78.0 \% \text { (of } \\
135 \text { ) } \\
\text { Males: } \\
43.1 \% \text { (of } \\
125)\end{array}$ & NR & NR & $\begin{array}{l}\text { Females: AOR: } \\
1.88(95 \% \mathrm{CI} \\
1.02-3.47) \\
\text { Males: AOR: } \\
1.18(95 \% \mathrm{CI} \\
0.61-2.29)\end{array}$ \\
\hline \multirow[t]{3}{*}{ Coyle, 2006} & $\begin{array}{l}\text { Frequency of } \\
\text { sexual } \\
\text { intercourse } \\
\text { previous } 3 \\
\text { months }\end{array}$ & $\begin{array}{l}12 \\
\text { months }\end{array}$ & NR & NR & NR & NR & NR & NR & $\begin{array}{l}\text { Ratio of } \\
\text { adjusted } \\
\text { means: } 0.12 \\
(P=0.24)\end{array}$ \\
\hline & $\begin{array}{l}\text { Number of } \\
\text { sexual partners } \\
\text { previous }\end{array}$ & $\begin{array}{l}12 \\
\text { months }\end{array}$ & NR & $\mathrm{NR}$ & NR & NR & NR & NR & $\begin{array}{l}\text { Ratio of } \\
\text { adjusted } \\
\text { means: } 0 \\
(P=0.57)\end{array}$ \\
\hline & $\begin{array}{l}\text { Sexual initiation } \\
\text { (among sexually } \\
\text { inexperienced at } \\
\text { baseline) }\end{array}$ & $\begin{array}{l}12 \\
\text { months }\end{array}$ & NR & NR & $\mathrm{NR}$ & NR & NR & NR & $\mathrm{N} / \mathrm{A}$ \\
\hline $\begin{array}{l}\text { Milhausen, } \\
2008\end{array}$ & $\begin{array}{l}\text { Frequencies } \\
\text { (number of } \\
\text { events in } \\
\text { previous six } \\
\text { months) of } \\
\text { Vaginal Sex }\end{array}$ & $\begin{array}{l}12 \\
\text { months }\end{array}$ & NR & $16.67^{*}$ & $\mathrm{NR}$ & NR & $17.94^{*}$ & NR & $\begin{array}{l}\text { Relative } \\
\text { change: } \\
-7.07 \% \\
(\mathrm{P}=0.65 \\
95 \% \mathrm{CI}-35.09- \\
49.29)\end{array}$ \\
\hline Sherr, 2013 & $\begin{array}{l}\text { Sexual } \\
\text { intercourse } \\
\text { within the last } \\
\text { three weeks }\end{array}$ & $\begin{array}{l}6 \\
\text { months }\end{array}$ & NR & NR & $\mathrm{NR}$ & NR & NR & NR & $\begin{array}{l}\text { B:-0.15 } \\
(P \geq 0.05 \\
95 \% C I-0.331- \\
0.032)\end{array}$ \\
\hline \multirow[t]{2}{*}{$\begin{array}{l}\text { Philliber, } \\
2002\end{array}$} & $\begin{array}{l}\text { Chose not to } \\
\text { have sex under } \\
\text { pressure }\end{array}$ & 3 years & NR & NR & $\mathrm{NR}$ & NR & NR & NR & NR \\
\hline & Ever had sex & 3 years & $26 \%$ & 63 & NR & $25 \%$ & 72 & NR & $\mathrm{P}<0.05$ \\
\hline \multirow[t]{2}{*}{$\begin{array}{l}\text { Jemmott, } \\
1992\end{array}$} & $\begin{array}{l}\text { Coitus in the } \\
\text { last } 3 \text { months }\end{array}$ & $\begin{array}{l}3 \\
\text { months }\end{array}$ & NR & $\begin{array}{l}\text { Mean } \\
(\mathrm{SD}): 0.48(62)\end{array}$ & NR & NR & $\begin{array}{l}\text { Mean } \\
(\mathrm{SD}): \\
0.60(53)\end{array}$ & NR & $\begin{array}{l}\text { Mean } \\
\text { difference: } \\
-0.12(95 \% \text { CI } \\
-0.27-0.3)\end{array}$ \\
\hline & Number of days & 3 & NR & Mean & NR & NR & Mean & NR & Mean \\
\hline
\end{tabular}

Page 23/26 


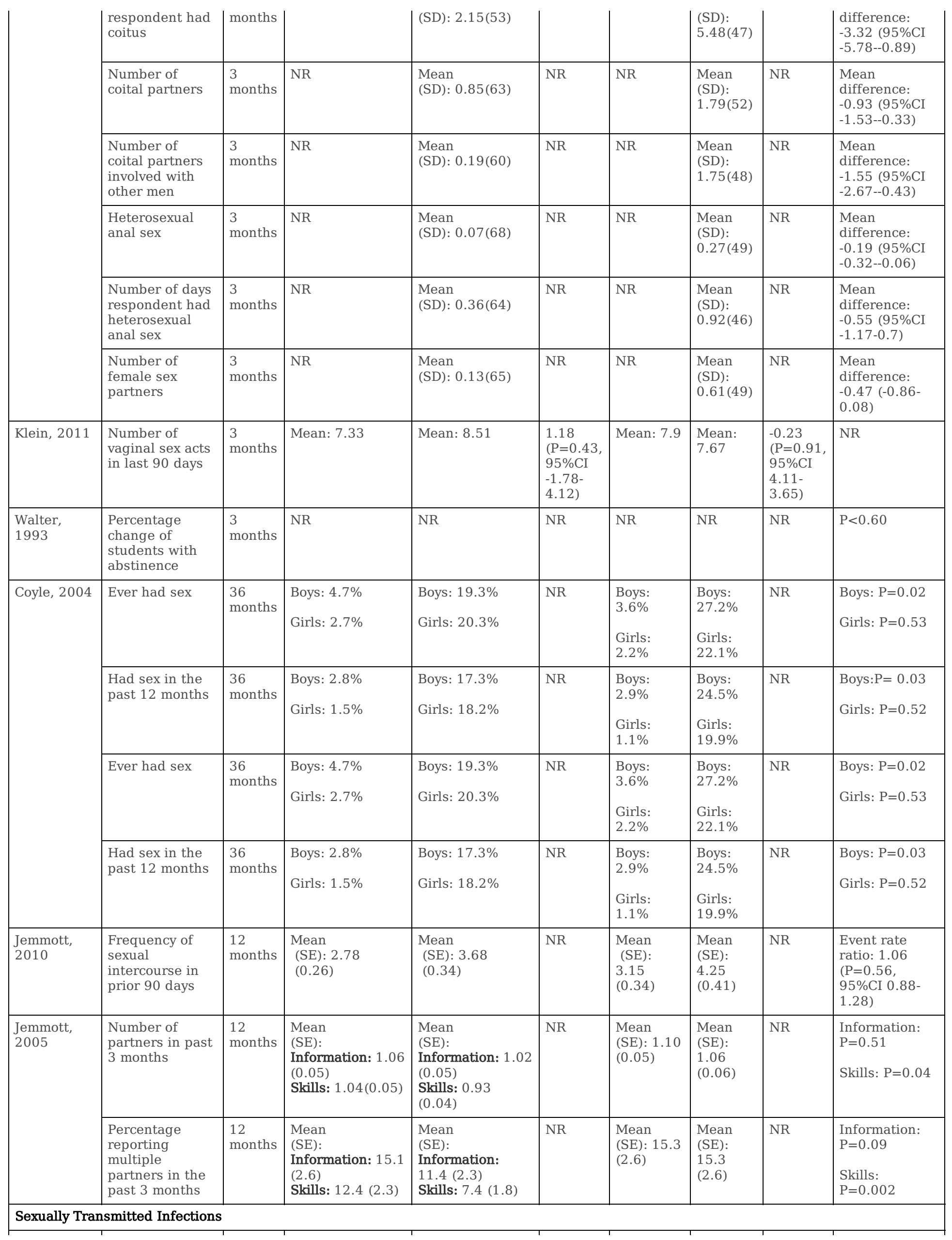




\begin{tabular}{|l|l|l|l|l|l|l|l|l|l|}
$\begin{array}{l}\text { Walter, } \\
1993\end{array}$ & $\begin{array}{l}\text { Percentage } \\
\text { change of } \\
\text { students with } \\
\text { STI incidence }\end{array}$ & $\begin{array}{l}3 \\
\text { months }\end{array}$ & NR & NR & NR & NR & P<0.10 \\
\hline $\begin{array}{l}\text { Scholes, } \\
2003\end{array}$ & $\begin{array}{l}\text { STD diagnosis } \\
\text { in prior 3 } \\
\text { months }\end{array}$ & $\begin{array}{l}6 \\
\text { months }\end{array}$ & NR & $3.50 \%$ & NR & NR & $3.60 \%$ & NR & $\begin{array}{l}\text { OR: 0.97 } \\
(P=0.93, \\
95 \% C I ~ 0.49- \\
1.96)\end{array}$ \\
\hline $\begin{array}{l}\text { Jemmott, } \\
2005\end{array}$ & $\begin{array}{l}\text { Percentage } \\
\text { testing positive } \\
\text { for an STD }\end{array}$ & $\begin{array}{l}12 \\
\text { months }\end{array}$ & $\begin{array}{l}\text { Mean } \\
\text { (SE): } \\
\text { Information: } 24.7 \\
(3.5) \\
\text { Skills: 23.6 (3.5) }\end{array}$ & $\begin{array}{l}\text { Information: } 16.0 \\
\text { (3.0) } \\
\text { Skills: } 10.8 \text { (2.6) }\end{array}$ & $\begin{array}{l}\text { Information: } \\
\text { P=0.44 } \\
\text { Skills: P=0.05 }\end{array}$ \\
\hline
\end{tabular}

Abbreviations: CSE (Comprehensive Sexuality Education); N (Number); SD (Standard Deviation); CI (Confidence Interval); NR (Not Reported); AOR (Adjusted Odds Ratio); RTR (Reduce the Risk); LN (Love Notes); PTC (Power Through Choice); IRR (Incidence Rate Ratio); ARR (Adjusted Risk Ratio); B (Linear Estimate); AO (Abstinence-Only); NI (No Intervention)

\section{Figures}

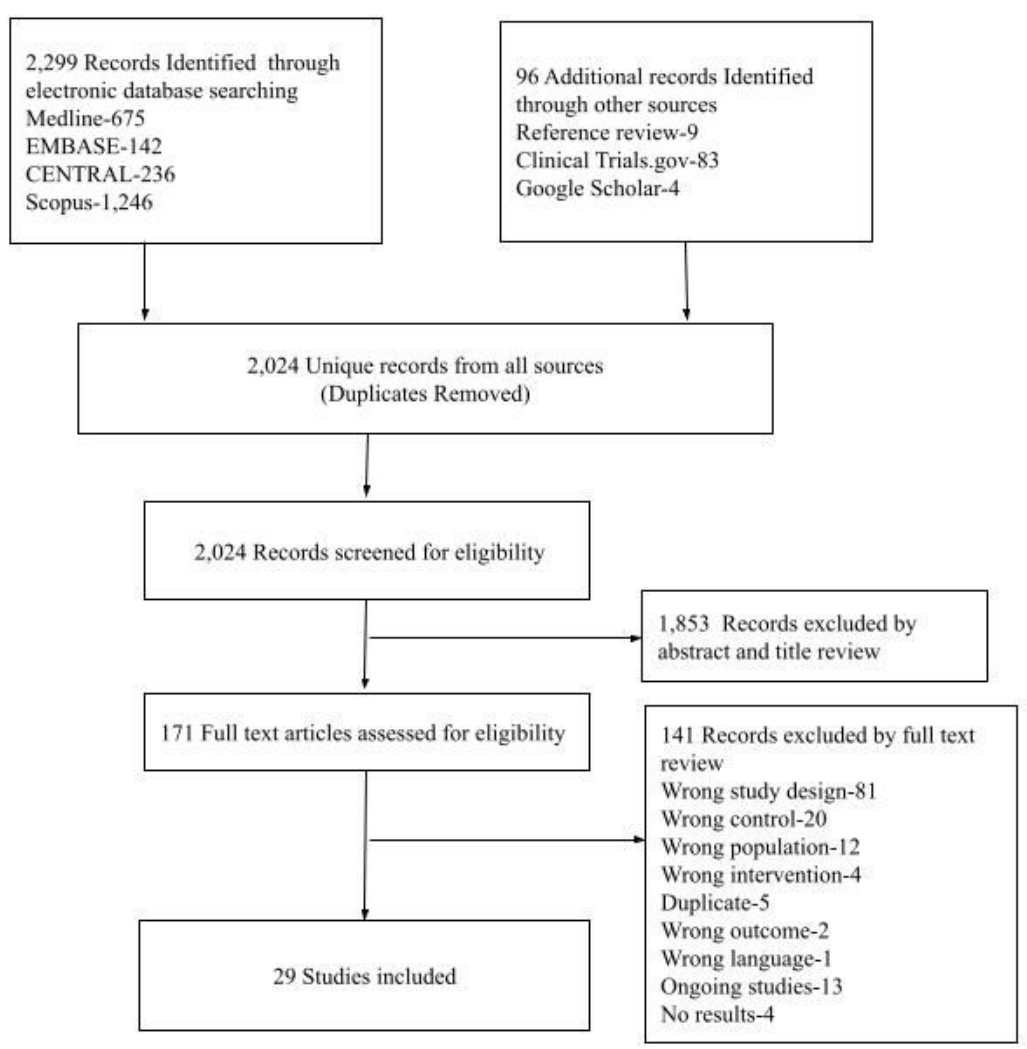

Figure 1

Study Selection Flow Diagram The flow diagram shows the number of studies included after each additional search method and subsequent screening processes, resulting in 29 studies total.

\begin{tabular}{|c|c|c|c|c|c|c|c|c|c|c|}
\hline Study or Subgroup & \multicolumn{2}{|l|}{$\operatorname{cSE}^{*}$} & \multicolumn{2}{|c|}{ No $\operatorname{CSE}^{\star}$} & Weight & \multicolumn{2}{|l|}{ Risk Ratio } & \multicolumn{2}{|c|}{$\begin{array}{c}\text { Risk Ratio } \\
\text { M-H, Random, } 95 \% \mathrm{CI}\end{array}$} & \\
\hline Diclemente 2005 & 13 & 219 & 20 & 241 & $3.2 \%$ & $0.72[0.36,1.40]$ & & $\longrightarrow$ & - & \\
\hline Kerr 2009 & 4 & 44 & 7 & 39 & $1.1 \%$ & $0.51[0.16,1.60]$ & & & & \\
\hline Oman 2018 & 220 & 435 & 250 & 445 & $95.7 \%$ & $0.90[0.80,1.02]$ & & & & \\
\hline Total $(95 \% \mathrm{Cl})$ & & 698 & & 725 & $100.0 \%$ & $0.89[0.79,1.00]$ & & $\checkmark$ & 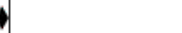 & \\
\hline Total events & 237 & & 277 & & & & & & & \\
\hline $\begin{array}{l}\text { Heterogeneity: Tau } \\
\text { Test for overall effec }\end{array}$ & $\begin{array}{l}0.00 ; \mathrm{Chi} \\
\mathrm{Z}=1.92\end{array}$ & $\begin{array}{l}\mathrm{I}^{2}=1.4 \\
\mathrm{P}=0.0\end{array}$ & $\begin{array}{l}0, d f=2( \\
55)\end{array}$ & $P=0.5$ & $0) ;\left.\right|^{2}=0 \%$ & & 0.01 & $\begin{array}{l}0.1 \\
\text { Favors [CSE] }\end{array}$ & 10 & 100 \\
\hline
\end{tabular}

\section{Figure 2}

Forest Plot of Meta-Analysis Results for Pregnancy Outcome Risk Ratio This forest plot shows the results of the analysis using the pooled RRs and 95\% Cl for studies included in the meta-analysis reporting on pregnancy. 


\section{Supplementary Files}

This is a list of supplementary files associated with this preprint. Click to download.

- Appendix.docx 